\title{
Ar-Ge Yönetimi Üzerine Stratejik Düşünceler: Temel Yetenek Tabanlı Bir Yönetişim Modeli Önerisi*
}

\author{
Cemalettin Öcal FİDANBOY** (D) \\ A. Selami SARGUT ${ }^{* * *}$ (D)
}

\begin{abstract}
ÖZ
Stratejik Ar-Ge yönetimi politikalarının etkili bir şekilde uygulanması, bu yaklaşımların kuramsal temellerle oluşturulmasına ve uygulamaya yönelik yönetim modelleriyle desteklenmesine bağlıdır. Araştırma ve geliştirme yapan örgütleri rakipleri karşısında farklı kılacak en önemli faktör, kabiliyet ve yetenekler temelinde Ar-Ge aktiviteleri yapmaları ve mevcut yeteneklerini değerli, az bulunur, taklit ve ikame edilemeyen yeteneklere dönüștürebilmeleridir. Bu çalışma; Ar-Ge yönetimi faaliyetlerini kaynak tabanlı kuram ve temel yetenek tabanlı stratejiler çerçevesinde incelemekte ve Teknokent toplulukları bünyesinde uygulanabilirliği olan stratejik araşturma ve geliştirme politikaları belirlemeye yönelik kuramsal bir yönetişim modeli önermektedir. Geliştirilen bu model çerçevesinde, Teknokentlerdeki Ar-Ge işletmelerinde var olan ortak ve öncelikli temel yeteneklerin koordineli olarak yönetilmesinin, ulusal Ar-Ge performansında önemli atılımlar ve ani yükselmeler sağlayabileceği savunulmaktadır. Yapılan araştırmanın; araştırma ve geliştirmeye yönelik politikalar esasında gerçekleşen geleneksel Ar-Ge performansı belirleme yaklaşımlarından, Ar-Ge işletmelerinin beyin gücünü ve teknolojik imkânlarının entegrasyonunu esas alan kaynak tabanlı ve temel yetenekler temelli Ar-Ge yönetișimi stratejilerine geçişe kuramsal ve düşünsel bir katkı sağlaması amaçlanmıștır.
\end{abstract}

Anahtar Kelimeler: Ar-Ge Yönetimi, Strateji, Temel Yetenek, Teknokent

\section{Strategical Thoughts in R\&D Management: A Proposal of Core- Competence Based Governance Model}

\begin{abstract}
Effective implementation of strategic R\&D policies depends on establishing these approaches with theoretical foundations and supporting them with application-oriented models. The most important factor that will differentiate R\&D organizations from their competitors is that they carry out R\&D management activities based on core-competencies and transform their capabilities into valuable, rare, imitated and non-substitutable core-competencies in the eyes of customers. This study examines R\&D management activities within the framework of resource-based theory and core competence-based strategies and proposes a theoretical management model for determining strategic R\&D policies. Within the framework of this developed model, it is argued that effective management of common and prioritized core competencies of R\&D companies within Technopark may lead to improvements in national R\&D performance. The aim of this study is to make a theoretical and intellectual contribution to the transition to resource-based and core competence-based R\&D governance strategies based on the integration of the brain power and technological facilities of $\mathrm{R} \& \mathrm{D}$ firms in the traditional $\mathrm{R} \& \mathrm{D}$ performance determination approaches within the context of R\&D policies.
\end{abstract}

Keywords: R\&D Management, Strategy, Core-Competence, Technopark

\section{Giriş}

Ar-Ge çalışmaları, insanllğın ilerlemesine ve toplumsal yeniliklerin gerçekleştirilmesine imkân sağlayan en önemli faaliyetlerdendir. Bu çalışmaların gerçekleştirildiği Ar-Ge örgütü ise, uygun pazarlar için teknolojik yenilikleri araştrrmak maksadiyla sorumluluk alan örgüt tipidir (Abbey ve Dickson, 1983, s.363). Yaylalı ve arkadaşlarına (2010, s.13) göre, araştırma ve geliştirme faaliyetleri bilginin somut ürünler haline geldiği yüksek katma değerli bir dönüşüm sürecini ifade eder. Ar-Ge çalışmaları, araştırma ve geliştirme için gerekli olan bilginin meydana getirilmesi için gereken imkânların sağlandığ Teknokent veya Teknopark olarak adlandırılan işletme toplulukları bünyesinde gerçekleştirilir. Ar-Ge çalışmaları sırasında tutarlı ve doğru yönetim stratejilerinin kullanılması ve çalışanlar arasında etkin koordinasyon yetenekleri geliştirilmesi durumunda, ileri düzey Ar-Ge aktivitelerinde olağanüstü kapasitelere ulaşmak mümkün görünmektedir.

\footnotetext{
${ }^{*}$ Bu çalışma, Cemalettin Öcal Fidanboy tarafindan Başkent Üniversitesi’nde Prof. Dr. A. Selami Sargut danışmanlı̆̆ında hazırlanan "Ulusal Ar-Ge Politikaları Bağlamında Temel Yetenek Tabanlı Ar-Ge Yönetimi Yaklaşımı: Teknokentler Örneğg”" isimli doktora tezinden üretilmiştir.

${ }^{* *}$ Dr. Öğr. Üyesi, OSTiM Teknik Üniversitesi, ocal.fidanboy@ostimteknik.edu.tr

*** Prof. Dr., Başkent Üniversitesi, ssargut@baskent.edu.tr

Makalenin Gönderim Tarihi: 15.03.2021; Makalenin Kabul Tarihi: 12.10.2021
} 
Ar-Ge çalışmalarıyla meydana getirilen yenilikçi ürünler, organizasyon açısından potansiyel ticari bir varlık haline gelir (Katila ve Ahuja, 2002, s. 1183). Lichtenber'e (2002) göre, Ar-Ge kapsamında gerçekleştirilen her bir dolarlık harcamanın sekiz kat daha fazla getiri sağlaması, araştırma ve geliştirme çalışmalarını oldukça avantajlı bir hale getirmiştir. Araştırma ve geliştirme çalışmaları; yeteneklerin geliştirmesi, yenilikçi ürün ve hizmetlerin geliştirmesi, icat ve proses yönetimi konularını da içerecek şekilde, mevcudu yenileştirme ve yeni işler ortaya koyma veya kullanilacak teknolojiyi de iyileştirmeyi içeren çeşitli araştırmalar şeklinde ifade edilmektedir (Matheson ve Matheson; 1999). Araştırma ve geliştirmeye yapılan yatırımlar, bilginin üretime ve kâr elde etmeye dönüştürüldüğü yatırımlardır (Matheson ve Matheson, 1999). Bu alanda yapılan harcamalar, bir ülkenin ekonomik ve teknolojik gelişmişlik düzeyini ortaya koyan en güçlü değişkenlerden biri olarak görülmektedir (Yaylalı vd., 2010, s. 14). Schilling ve Hill'e (1998, s.70) göre bir araştırma geliştirme örgütünün başarısı, mevcut kaynak ve yeteneklerini yeni ürün geliştirme hedefleriyle uyumlu hale getirmesine ve stratejik niyetini Ar-Ge portföyüyle doğru bir şekilde entegre edebilmesine bağlıdır.

Teknokent topluluklarn, işletmelerin kaynak ve yeteneklerini ortak havuzlardan elde edebilmesine imkân veren ve Ar-Ge portföyünün stratejik ve dengeli olarak paylaşılabilmesini sağlayan iletişim ve koordinasyon ortamlarıdır. Ar-Ge çalışmaları, sabır isteyen ve oldukça uzun süre alan yorucu aktivitelerden oluşur. Bu aktiviteler ancak gerekli sebat ve motivasyonun sağlandığı doğru bir iletişim ve koordinasyonun temin edildiği ortamlarda gerçekleşebilir. Teknokent toplulukları, Ar-Ge organizasyonlarına tam olarak bu noktada hizmet verebilen iletişimsel ortamları sağlamaktadır. Yenilikçi Ar-Ge çalışmalarının Teknokent toplulukları içinde gerçekleştirilmiş olmasının, ürünün pazara sürülme süreçlerinde de önemli faydaları bulunmaktadır. Ar-Ge çalışmaları sırasında ortaya çıkan yenilikçi bir fikir, temel araştırma safhasında görev yapan Ar-Ge uzmanları tarafından yaratılır. Yaratıcı bir fikrin ortaya çıkması, bireyin sahip olduğu beceri, kabiliyet ve yeteneklere bağlıdır. Ar-Ge çalışmalarının başarısında insan faktörünün ve kullanılan teknolojik kaynakların önemi dikkate alındığında; Ar-Ge uzmanlarının yetenekleri, teknolojik kaynakların kullanılabilirliği ve yenilikçi örgüt yapısının önemi ortaya çıkar. Ar-Ge yönetim stratejilerinin belirlenmesinde, kaynak tabanlı kuram ve temel yetenek tabanlı stratejiler çerçevesinde geliştirilecek yetenek bazlı yaklaşımlar, Ar-Ge performansının yükseltilmesine önemli katkılar sağlayabilir.

Dijital çağın kaçınılmaz bir unsuru olan araştırma ve geliştirme çalışmaları, çağdaş bir örgütün diğer örgütlerle rekabet edebilmesi ve üretimini daha kârlı bir hale getirebilmesi için zorunlu hale gelmiştir. $\mathrm{Bu}$ nedenle, Ar-Ge yönetimi çalışmalarını doğru stratejilerle şekillendirebilmek oldukça önemlidir. Günümüz dünyasında bir Ar-Ge örgütünün başarısı için sadece teknoloji ve pazarlama tabanlı stratejiler yeterli olmamaktadır. Bununla birlikte iç çevre odaklı stratejilere de ihtiyaç vardır. Teknokent veya Teknopark olarak adlandırlan örgüt toplulukları, Ar-Ge yönetiminde temel yetenek tabanlı stratejilerin uygulanması için oldukça elverişli ortamlardır. Yenilikçi ürünler için gerekli olan bilgi ve teknolojiyi temin etmek veya mevcut profesyonel bilginin içsel koordinasyonu aracllığılla yenilikçi ürünler üretmek, ancak temel yetenek tabanlı yaklaşımlarla mümkün olacaktır. Küresel rekabetin en yüksek seviyelere ulaşıtğı çağımızda, Ar-Ge firmaları teknolojiyi sistematik bir şekilde yönetmek, koordinasyon ve iletişime dayalı pazarlama stratejileri geliştirmek ve Ar-Ge profesyonellerinin beceri ve yetenek düzeylerine hâkim bir şekilde temel yetenek tabanlı stratejiler geliştirmek mecburiyetindedir. Teknoloji, bilim tarafından sunulan imkânlardan yararlanarak yenilikçi ürünlerin veya hizmetlerin üretimine her zaman destek verecektir. Ar-Ge'de yüksek teknoloji kullanılarak gerçekleştirilen bilimsel araştırmalar, elbette ki yeni buluşların yapılmasına ve yeni verilerin elde edilmesine vesile olacaktır. Fakat Ar-Ge performansında yüksek ve anlamlı sonuçlara ulaşmak, teknolojik kaynakların ve yeteneklerin kaynak tabanlı bir yaklaşımla ve bütünleşik bir şekilde uygulamalı araştırmaların girdisi olarak kullanılması ile mümkündür. Ar-Ge için teknolojiye ve pazarlamaya yapılan yatırımlar kadar, Ar-Ge uzmanlarının bilgi, beceri ve yeteneklerine de yatırım yapılması gereklidir. Yeniliklerin, iç çevreye yönelik sistematik ve uygulanabilir stratejik yaklaşımlar tasarlanmadan yapılması oldukça sınırlı bir çaba olacaktır. Kısacası, profesyonel olarak planlanması zorunlu olan araştırma ve geliştirmeye yönelik stratejiler, etkili inovasyonun kaçınılmaz girdilerinden birisidir. Araştırma geliştirme stratejilerinin ve bu stratejiler temelinde ölçülecek performansın bütüncül ve bütünleşik olarak belirlenmesi, ulusal araştırma geliştirme faaliyetlerine yönelik politikaların doğru şekilde oluşturulması açısından önemlidir. Bu açıdan bakıldığında; teknokent topluluklanı içinde uygulanacak Ar-Ge yönetimi 
stratejilerinin ve performans kapsamındaki uygulamaların temel yetenek tabanlı bir yaklaşımla ve bütünleşik bir mantıkla ele alınması, araştırma ve geliştirme performansının yükseltilmesine önemli faydalar sağlayacaktır.

$\mathrm{Bu}$ makalede; teknokent topluluklarında kaynak temelli stratejilerin geliştirmesi için Ar-Ge politikaları bağlamında bir Ar-Ge yönetişimi modeli önerisi yapılmaktadır. Çalışmada öncelikli olarak Ar-Ge yönetimi ve Ar-Ge performansının kuramsal altyapısı incelenmiş ve Ar-Ge performansına yönelik yazın taramalarının sonuçlarına yer verilmiştir. Ardından Ar-Ge örgütlerinin performans ölçümlerini hiyerarşik olarak açıklayan Teknoloji Değer Piramidi (TDP) anlatılmıştır. Bahsedilen çerçeveyi daha iyi anlayabilmek amaciyla, kaynak tabanlı kuram ve temel yetenek tabanlı yaklaşımın temel prensipleri incelenmiştir. Ardından temel yetenek tabanlı yaklaşımın Ar-Ge performansıyla ilişkileri ele alınarak, teknokentlerde temel yetenek tabanlı stratejilerin uygulanmasına yönelik olarak geliştirilen model önerileri, kuramsal ve uygulamaya dönük örneklerle tartısılmışır.

\section{Ar-Ge Yönetimi İçin Stratejik Yaklaşımlar}

Ar-Ge örgütlerinde gerçekleşen yönetimsel çalışmalar; bu örgütlerde yaşanan yüksek belirsizlik ortamı, çalışanların yeteneklerine bağlı olma zorunluluğu, ileri düzey teknolojik yetkinlik ihtiyaçları gibi nedenlerle, diğer örgütler için gerekli olan yönetimsel yaklaşımlardan daha farklı yaklaşımlara ihtiyaç duyar. Ar-Ge yönetiminde yaşanan en önemli sorunlar, değişik becerilere sahip olan çalışanların birlikte çalşsma etkinliklerinin doğru bir şekilde koordine edilememesinden, teknolojik kaynakların bütünleşik bir şekilde kullanılamamasından ve teknik anlamda oldukça yetkin olan iş gücünün farklı ve yenilikçi bir yönetim anlayışına ihtiyaç duymasına rağmen, yöneticilerin geleneksel yönetici yaklaşımlarından vazgeçememelerinden kaynaklanır. İşin özü, Ar-Ge yönetiminde çalışanların bir amaç doğrultusunda ve ekip bilinci içinde iş çıkarma potansiyelinin yüksek seviyelerde tutulabilmesi için, klasik yönetim yaklaşımlarından daha farklı yaklaşımlara ihtiyaç vardır. Ar-Ge yapan firmaların yönetimindeki temel mesele; personelin sahip olduğu yüksek beceriler nedeniyle, bu tip çalışanların yönetilebilmesine imkân sağlayacak yönetsel yaklaşımların henüz tam olarak kuramsallaşamamış olmasıdır. Ar-Ge örgütlerindeki yönetim yaklaşımlanı; yatay örgütsel yapıya yatkınlık, sanal takımlar şeklinde iş yapabilme ve kendi kendini yöneten organizasyon olma gibi özellikleri nedeniyle güncel çevik yönetim yaklaşımlarına daha uygun bir niteliktedir. Örneğin Ar-Ge çalışmalanının oldukça yoğun bir şekilde gerçekleştirildiği yazilım sektörü dikkate alındığında; bu sektördeki geleneksel yönetim yaklaşımları, günümüzde yerini çevik yönetim modellerine bırakmak zorunda kalmıştr. Yazılım sektöründe çalışanların çevik yönetim tarzlarına yakın olmalarının temel nedenleri; bu sektörde çalışan bireylerin diğer örgüt tiplerine göre daha yüksek becerilere sahip olmalan, sanal takımlar şeklinde çalışabilmeleri ve yönetim açısından daha fazla özerkliğe ihtiyaç duymalarıdır. Bu tip çevik örgütler;

- Merkeziyetçi bir yönetim tarzı yerine âdem-i merkeziyetçi bir yönetim tarzını benimsemekte,

- Yönetimsel süreçler yerine insan ilişkilerini esas almakta,

- Doğrusal bir yönetim tarzı yerine, yinelemeli yaklaşımları tercih etmekte,

- Önceden planlama yerine, zamanında planlamayı önemsemekte,

- Yönetilmek yerine, kendi kendilerini yönetmeyi tercih etmekte,

- Süreç odakllık yerine, müşteri odaklı davranmakta,

- Komuta ve kontrol tarzı bir liderlik yerine, işbirlikçi ve hizmetkar bir liderlik anlayışını benimsemekte ve beceri ve yetkinlik bazlı bir yönetim yaklaşımlarıly daha performanslı işler çıarmaktadır.

İleri seviyedeki Ar-Ge çalışmaları, yüksek niteliklere sahip çalışanları bünyesinde barındırabilen örgütler tarafından gerçekleştirilebilmektedir. Günümüzde; bünyesinde bilişsel açıdan diğer sektörlere göre daha becerikli bireyleri barındırmış, faaliyetlerini işletmenin tüm fonksiyonel seviyelerine aktarabilmiş ve bünyelerinde profesyonel Ar-Ge bölümleri veya Ar-Ge merkezleri oluşturmuş olan örgütleri birer Ar-Ge örgütü olarak tanımlamak mümkündür.

Ar-Ge yönetimini zorlaştıran etmenlerin başında; bu tip işletmelerdeki değişim hızının yüksek olması, teknolojik altyapıdaki karmaşıklık, işletmenin yapısal değişiklikleri hızlı bir şekilde yapamaması, örgütsel yeteneklerin sürekli değişimi, serbest çalışma ve yaratıcılık olanaklarının azlığı, örgüt yapısının geleneksel 
hiyerarşiye dayalı ve otoriter bir yaklaşımla devam ettirilme niyeti gibi konular gelmektedir (Barutçugil, 2009). Bu olumsuzlukların üstesinden gelebilmek ve Ar-Ge yapan işletmelerin daha yüksek performans gösterebilmelerini sağlamak için, mevcut yönetim stratejilerinde önemli değişiklere gidilmesi gereklidir. Bu tip işletmelerde; hali hazırda etkin bir şekilde kullanılan dış çevre odaklı stratejilerin yanında, işletmelerin iç çevrelerine odaklanan yetenek bazlı stratejilerin oluşturulması, örgüt yapısının kabiliyet ve yetenekleri esas alan stratejilerle geliştirilmesi büyük önem arz etmektedir. Araştırma geliştirme yapan işletmelerin yönetilmesinde karşımıza çıkan ana sorunlardan bir diğeri de; klasik yönetici yaklaşımlarıyla, Ar-Ge çalışanlarının değerlerinin ve beklentilerinin birbirine tamamen ters bir mecrada bulunmasıdır. Bu açıdan bakıldı̆̆ında; geleneksel yönetim yaklaşımlarında yöneticinin temel odağı örgütün kendisiyken, bir Ar-Ge uzmanının odağı araştırdığı konu ve araştırma sonuçlarıdır. Geleneksel bir yönetici insanları yönetmeye odaklanırken, bir Ar-Ge uzmanı araştırdığı konudan elde edebileceği sonuçları yaratma arzusundadır. Klasik anlamda bir yöneticinin temel yaklaşımı işletmeye para kazandırmak ve kar elde etmek iken; bir araşırmacının odaklandığı şeyler, araştırma projelerinin uzun vadeli başarıları, araştırma sonuçlarının insanlığa ve topluma katkıları olmaktadır. Bir araştırmacı, elde ettiği sonuçların entelektüel kazanımlarından mutlu olurken, bir yönetici işletmesinin vizyonu doğrultusunda işletmeye kazandırdığı kar ile mutlu olmaktadır. Geleneksel bir yönetici risk almayı severken, araştırmacılar risk almaktan kesinlikle hoşlanmazlar. Yönetici unvanına sahip çalışanlanın temel hedefi, araştırma ve geliştirmeye yönelik faaliyetlerini takımlar olarak yönlendirmek iken; Ar-Ge yapan çalışanlar temel araştırma aşamalarında işlerine bireysel olarak odaklanmayı isteyebilmektedir (Barutçugil, 2009). Bir yöneticiyle araştırma yapan birey arasındaki farklar sadece bu tip örneklerle sınırlı olmayıp, birçok davranışsal boyutta da ele alınabilir. İdeal bir Ar-Ge yönetimine ulaşılabilmesi için; araştırmacıların tutum ve davranışlarını anlamak ve yönetim stratejilerini kaynak temelli yaklaşımlarla güncellemek gerekir. Ar-Ge örgütlerinde Ar-Ge çalışmalarını yönetenlerin seçimine ayrı bir önem vermek ve yöneticinin arzu edilen liderlik bilgilerine ve becerilerine sahip olmasını sağlamak önemlidir. Bu konu çerçevesinde Katz ve Allen'in (1985), araştırma ve geliştirme yapan işletmelerde görev yapan işlevsel yöneticilerin ve proje yöneticilerinin proje performansına etkilerini incelediği çalışma oldukça ilginçtir. Bahsi geçen araştırmanın sonuçlanı; davranışsal etkilerin Ar-Ge proje yöneticisinde, yapılan faaliyetin teknik içeriğinin işlevsel yöneticide bulunduğu durumlarda, işletmenin çok daha yüksek performansı olduğunu göstermiştir (Katz ve Allen, 1985). Bu araştırma, Ar-Ge işletmelerinin matris organizasyon yapılanmalarında çok daha fazla verim sağlayabileceğini de savunmaktadır. Kısacası Ar-Ge yönetiminde performans, sadece dış çevre odaklı nicel göstergelerle ölçülmemelidir. Aynı zamanda Ar-Ge personelinin içinde bulunduğu örgütün davranışsal boyutlarının da nitel ve nicel metriklerle performans ölçümlerine katılması gerekir. Bununla birlikte yazında yer alan metrikler incelendiğinde; bu metriklerin daha çok nicel verileri kapsadığı, yetenek bazlı yapıya dayalı bir mantıkla oluşturulmadığı ve ArGe yapan işletmelerin yöneticilerinde bulunması önerilen yönetimsel yeteneklerle alakalı ölçümleri kapsamadığ görülmektedir.

\subsection{Kaynak Tabanlı Yaklaşım}

Stratejik yönetim yazınında yapılan araştırmaların önemli bir kısmı, endüstriyel temelli bakışla organizasyonun dışından elde edebileceği fırsatlara ve diş çevresiyle iletişimi sonucunda meydana gelebilecek tehditlere odaklanmaktadır. Bununla birlikte son yıllardaki eğilim; kaynak temelli kuramın, endüstriyel bazlı bakış tarzını bütünleyen özelliklerinin bulunduğuna işaret etmektedir (Wernerfelt, 1984; Rumelt, 1987; Barney, 1991; Wright vd., 2001). Örgütün diş çevresiyle etkileşmesinden doğan tehditler ile firsatların yerine, içsel kaynak yapısına yönlenen kaynak bazlı bakış açısı; endüstriyel bazlı yaklaşımların bütünleyicisi olmasıyla birlikte, stratejik yönetimde yeni bir paradigma oluşturma yönündeki ilerlemesini hizla sürdürmektedir (Wernerfelt, 1984; Rumelt, 1987; Barney, 1991; Boxall, 1996; Wright vd., 2001).

Dinamik Kaynak Temelli Örgüt Kuramı, Bilgi Bazlı Kuram, Yetenekler Kuramı veya Temel Yetenek Tabanlı Stratejiler olarak kuramsallaştırılan kaynak bazlı kuram, ilk defa Wernerfelt (1984) tarafindan ortaya atılan bir araştırma ile gündeme getirilmiştir. Benzer bakış açıları, Rumelt (1987) tarafindan da ele alınarak stratejik yönetim araştırmalarının kaynak temelli araştırmalara doğru yönlendirilmesi sağlanmıştır. Barney (1991), işletme kaynaklarıyla elde edilebilecek sürdürülebilir rekabetçi avantajlarla ilgili araştırmasıyla, kaynak bazlı bakışın kuramsal esaslarını daha da iyileştirmiştir. Bu yıllarda Barney'in (1986b), 
işletmenin içsel özelliklerini ele alan ve örgütsel kültürle rekabetçi avantaj ilişkisini vurgulayan araştırması, bu bakışın daha da derinleşmesini sağlamıştır. Wernerfelt (1984) ile Prahalad ve Hamel (1990) tarafindan ortaya atılan Temel Yetenek Bazlı Stratejiler, daha sonra Barney'in de etkileriyle Kaynak Temelli Bakış adıyla yönetim bilimlerinde önemli bir kuram haline gelmiştir. Foss'a (1996) göre bu stratejiler, rakipleri dikkate alarak örgütsel davranış oluşturma veya içsel kaynaklanı ve örgütsel davranışlanı iyileştirme sanatıdır. Grant (1996), tanımladığı Bilgi Bazlı Örgüt Kuramı ile, kaynak bazlı bakış açılarının kuramlaşmasına önemli katkılar sağlamıştır. Srivastava ve arkadaşları (2001), kaynak bazlı yaklaşımın pazarlama sistemleriyle etkileşimini incelemiştir. Bununla birlikte örgütsel yazında kaynak bazlı yaklaşımın insan kaynakları yönetimiyle etkileşimlerini ele alan birçok araştırma da mevcuttur (Boxall, 1996; Lepak ve Snell, 1999; Wright vd., 2001).

Kaynak bazlı bakış, kaynakların heterojen olma durumunu veya bir başka deyişle devinimsizliğini yani mobil olmama halini araştırır (Barney, 1991, s.104). Kaynakların heterojenliği bakış açısında, değişik tiplerdeki örgütlerin değişik tiplerde kaynakları olduğu varsayılır. Kaynak Bazlı Örgüt Kuramı, kaynakların heterojenliği bakış açısını desteklemektedir. Bu kuramın bakış açısına göre organizasyonlar kendilerine özel olan iç nitelikleri sebebiyle, işletme dışıyla kendilerine özel bir etkileşim sağlamaktadır. Kendine özel bakış açısı, işletmeye rakipleri karşısında yüksek seviyede bir rekabet avantajı getirir. Kaynak heterojenliği; kaynak sunumunun esnek olmamasını, taklit edilmesinin oldukça pahalı olmasını ve bunların neticesinde de az miktarda örgütün bahsedilen çeşitlilikteki kaynaklara sahip olmasıyla birlikte bünyesinde önemli bir rekabet avantajını bulundurabileceğini söyler. Bu nedenle işletmeler, mobil özelliği bulunan kritik nitelikteki kaynaklarını azaltmaya gayret gösterirler (Barney, 1991, s.105).

\subsection{Temel Yetenek Kavramı}

Temel yetenek kavramı, yönetim ve strateji yazınında ilk kez Prahalad ve Hamel (1990) tarafindan ortaya atılmış ve "beceri ve teknolojilerin bütünleştirilmiş bir yığını" şeklinde ifade edilmiştir. Temel yetenekler, örgüt için rekabet avantajı sağlayabilen ve örgütü diğer işletmelerden önemli derece farklı kılabilen özel ve öncelikli yeteneklerin bir bileşimi anlamına gelmektedir. Temel yetenekler, örgütlerin ellerinde bulundurdukları becerilerle örgütün teknolojik imkanlarının nasıl entegre edebileceğine odaklanan ve bu tip bir entegrasyon neticesinde sağlanabilecek imkanları gündeme getiren bir sürecin sonuçlarını ifade eder (Prahalad ve Hamel, 1990, s. 4). Temel yetenekler, organizasyonun değişik işlevsel düzeylerinde yer alan yeteneklerin birbirleriyle yoğun bir şekilde etkileşmesinden meydana gelen ve örgütün bütününe ulaşan yeteneklerin toplamıdır (Torkkeli ve Tuominen, 2002, s. 273-276). Temel yeteneklerin örgütlerdeki anahtar görevinin sebebi, yeteneklerin örgütsel hedeflere ulaşmak için gereken işletme varlıklarının bütünleşmiş halde gelişimine ve iyileşmesine imkân vermesidir (Sanchez ve Henee; 1997). Temel yetenekler sadece tek bir ürün veya hizmetle sınırlı tutulamaz (Prahalad ve Hamel, 1990). Bu nedenle, bu tarz yeteneklerin birçok farklı ürün veya hizmete dönüşme kapasitesi bulunmaktadır.

Temel yetenekler, işletme personelinin yönetime gönüllü bir şekilde katılmasına imkân veren bir iletişim mekanizmasıdır (Prahalad ve Hamel, 1990). Jenster ve Pedersen'a (2000) göre temel yetenekler, organizasyonun farklı aktivitelerinde daha çok profesyonelleştiği ve ileride daha çok başarılar temin edebileceğini fark ettiği aktiviteler şeklinde de tanımlanabilir. Prahalad ve Hamel, (1990), yetenekleri beş temel kriter esasında ele almaktadır. Bu kriterler; bireysel yeteneklerin organizasyonel teknolojiyle ve yetenekleriyle entegre edilmesi, öğrenebilme, örgüt dışına yarar sağlayan yetenek mevcudiyeti, yeteneğin diğer örgütler tarafından zor taklit edilebilmesi ve yeteneğin farklı iş ortamlarına girilmesini kolaylaştırabilmesidir (Major vd., 2001). Temel yetenek kavramı; bilgi temelli, farklı olan ve organizasyona özel yetenekler olması nedeniyle oldukça zor taklit edilebilen kabiliyetlerden ve değerli olan varlıklardan oluşmaktadır (Pitt ve Clark, 1999). Leonard-Barton (1992) temel yeteneklerin bilgi yönüne ve öğrenme ile ilişskilerini vurgulamış ve bir işletmede meydana gelmesi için dört temel boyutta incelenebileceğini söylemiştir. Bu boyutlar; personel bilgisi ve beceriler, teknik sistemler, bilginin meydana gelmesine katkıda bulunan yönetim sistemleri ve bilgi yönetimini oluşturma ve kontrolüne imkân sağlayan değerler ve normlardır (Leonard-Barton, 1992). İşletmelerin ellerinde bulundurdukları temel yeteneklerin, rekabetçi avantaj sağlama açısından önemli faydaları bulunmakta olup, bu yetenekler örgütsel hedefleri de doğrudan etkileyebilmektedir (Mooney, 2007). Temel yeteneklerin; organizasyon için değerli olan, oldukça kıt, kolay 
taklit edilmesi mümkün olmayan ve zor ikame edilebilen niteliklere sahip olan yetenekler olduğu söylenebilir (Barney, 1991, s. 112).

\subsubsection{Temel Yetenek Nitelikleri}

Temel yeteneklerin doğru bir şekilde tanımlanabilmesi için, bu yeteneklerin niteliklerini bilmek ve hangi niteliklerin örgütsel kabiliyetlere temel yetenek özelliği kazandırdığını anlamak oldukça önemlidir. Yönetim ve strateji alanında, temel yetenek niteliklerini ortaya koyan çeşitli araştırmalar bulunmaktadır. Barney (1991), tarafından önerilen VRIO/VRIN çatısı, örgütün temel yetenek niteliklerini kuramsal bir açıyla tanımlar. Kurama göre bu nitelikler; değerlilik (valuable), nadir bulunurluk (rare), tam taklit edilemezlik (inimitable) ve ikame edilemezlik (non-substitutable) niteliklerinden meydana gelir (Barney, 1991).

Değerlilik: Bu nitelik; işletmenin müşterileri, dış çevresi ve diğer sektörler açısından değerli olduğunu açık bir şekilde ifade eden yetenekleri ifade eder. Bu tarz bir yeteneği değerli kılan, bu yeteneğin organizasyona özgü yetenekler olması ve müşteri tarafindan sıradan bir yetenek gibi algılanmamasıdır. Müşteri gözünde değerli olan bir temel yeteneğin, aniden ortadan yok olması veya bitmesi imkansızdır. Bir temel yeteneğin değerliliği, ilgili yeteneğin uzun bir süre içinde sürekliliğini muhafaza edebilmesine bağlıdır (Grant, 1991).

Nadir Bulunurluk: Nadir bulunurluk, örgütte mevcut olan yeteneğin yer aldığı endüstri içinde hiç olmaması veya oldukça az bulunması durumunu ifade eder. Bir kaynak, rakipler arasında ne kadar kıt ise, o kaynağın nadir bulunur temel yeteneklerden birisi olduğunu söylemek mümkündür. Bu tarz kaynak veya kabiliyetlerin farklı örgütlerde de bulunması, örgütün rekabetçi avantaj oluşturma gücünü azaltmaktadır (Harrison v.d., 1991). Örgütlerin kabiliyetlerinin az bulunurluk çerçevesinde incelenmesinde sorulmas1 gereken, bu kabiliyetin başka rakip organizasyonlarda bulunup bulunmadı̆̆1 sorusudur. Temel yeteneklerin nadir bulunurluk niteliğine örnek verilecek olursa, akla ilk gelen isimler NEC ile AT\&T işletmeleri olacaktır. Bu işletmelerin temel yetenekleri, diğer işletmelerle kıyas edildiğinde oldukça kıt bir niteliğe sahiptir. Bu nedenle bu tip örgütler az bulunurluk niteliği gereği, diğer firmalara kıyasla daha fazla sürdürülebilir rekabet avantajına sahiptir (Campbell ve Luchs, 2002).

Taklit Edilemezlik: Bu niteliğin en önemli özelliği, işletmenin sahip olduğu bir becerinin veya kabiliyetin taklit edilmesinin olanaksız veya maliyetli olmasıdır. Fiziksel çalışma ortamları veya teknolojik hususlar gibi birçok maddi hususların taklit edilebilmesi oldukça kolayken; örgütsel kültür, ekip çalışmasına yatkınlık benzeri yeteneklerin taklidi oldukça zordur. Taklit edilemezlik; nedensel belirsizlik, sosyal karmaşıklık ve tarihsel bağımlılık alt boyutları çerçevesinde de ele alınabilmektedir. Bir yeteneğin temel bir yetenek olduğunun delillerinden bir diğeri de, o yeteneğin firma içindeki oldukça fazla bireyde bulunuyor olmasıdır. Iş̧letme içindeki bu tarz bir bütüncül yapı, başarısını tarih içindeki birikiminden almaktadır. Bir işletmenin başka bir işletmenin sahip olduğu yeteneği kolayllkla öğrenebilmesi, bu niteliğin temel bir yetenek olması özelliğini oldukça zorlaştıran bir durumdur. Yeteneğin temel bir yetenek olarak kabul edilebilmesi için, uzun bir zaman kolaylıkla taklit edilememesi gerekir. İşletme yönetimlerince verilen küçük kapsamdaki kararların, büyük kapsamdaki kararlara kıyasla taklidi oldukça zordur. Rakip işletmeler başka bir işletmenin vereceği büyük kapsamdaki kararları kolay bir şekilde taklit edebilirken, küçük kapsamlı kararları yeterince izleyemedikleri için, bu çerçevede oluşan temel yetenekler kolaylikla kopyalanamamaktadır (Campbell ve Luchs, 2002). Örgütteki bazı kabiliyetlerin rakip işletmeler tarafindan kolaylikla görülememesi de bu yeteneklerin taklit edilmesini oldukça zor bir hale getirerek, bu kabiliyetlerin temel yetenek özelliği kazanmasına vesile olur. Rakip işletmeler, temel yeteneklerin var olduğunu hissetmekle birlikte, kolay bir şekilde takip edememektedir (Grant, 1991, s. 125).

Taklit edilemezlik niteliği üç temel açıdan incelenebilmektedir. Bu açılar; yol bağımlılık, nedensel belirsizlik ve ekonomik caydırıcllık olarak tanımlanır.

Yol Bağgmhllk: Bir işletmeyi rakip işletmelerden ayıran en önemli unsurlardan birisi, örgütsel yeteneğin kolay bir şekilde çözümlenememesi veya aynı tip kaynaklarla yeniden üretilmesinin zor olmasıdır. Başka bir ifadeyle, işletmenin sahip olduğu temel bir yeteneği taklit etmeye çalsşan başka bir işletme, bu yeteneği taklit edebilmek için tüm tarihsel birikim sürecinden yeniden geçmelidir. Bu açıdan bakıldığında, tersine mühendislik araştırmaları taklit için olanak sağlamadığında, bu yeteneğin bir temel yetenek olduğu kesinleşir. Çünkü taklit etmek amacıyla yapılan tersine mühendislik çalışmalarının pahalı olması ve fazla 
süre gerektirmesi, taklit etme isteğinden vazgeçmeye ve rakip işletmenin bu yeteneği kendi işletmesine kopyalayamamasına sebep olmaktadır. Örgütlerin parasal değeri yüksek, önemli bir araştırma-geliştirme potansiyeline sahip ve birikimli bir tarihsel süreç gerektiren süreçlerini, yol bağımlı (path-dependent) süreçler olarak tanımlamak mümkündür (Taymaz, 2001). Bir örnek vermek gerekirse; kahvaltı sektöründe dünya çapında bir tanınırlı̆̆ olan Kelloggs firmasının en önemli temel yeteneğinin, şirket içinde gerçekleştirilen her bir süreç adımını yol bağımlı ve birikimsel olarak geleceğe taşıma çabası olduğu söylenebilir (Javidan, 1998, s. 67).

Nedensel Belirsizllik: İşletmenin kaynaklarıyla kabiliyetlerinin taklit edilmesini zorlaştıran bir diğer sebep, yeteneğin neden ve sonuç ilişkisinin ana nedenlerinin açığa çıkarılmasında yaşanan zorluklardır. Bu durumda ortaya çıkan nedensel belirsizlik, örgütsel kaynak ve becerilerin kopyalanmasını zorlaştırmakta ve işletme için oldukça önemli bir rekabet avantajı oluşturmaktadır. Nedensel belirsizlik durumu, aktiviteler ve bu aktivitelerin sonuçları arasında nedensellik ilişkisi kurulmasını imkânsız bir hale getirmekte ve üretim kaynaklarının hareketliliğinin diğer şirketler tarafindan açık bir şekilde izlenmesini önemli ölçüde engellemektedir (Reed ve Defillippi, 1990). Rakip işletme, ilgili temel yeteneği ancak tersine mühendislik yapmak suretiyle nedensellik ilişkilerini anlayarak taklit edebilir (Javidan, 1998, s.67). Yeteneklerde bulunan örtük bilgi, dışarıdan gözlenenin çok daha fazlasını içerebilir. Bu sebeple, şirket aktivitelerinde nedenler ve sonuçları arasında mantıklı bir ilişki kurmak oldukça zor hale gelir (Reed ve Defillippi, 1990). Temel yetenekler içinde yer alan örtük bilginin fazlalığı, bu bilginin taklit edilmesini zorlaştırır. Bu durumda, neden ve sonuç ilişkileri bütünüyle çözümlenemediği için, temel yetenek olarak ifade edilebilen bu yeteneği kolayca taklit etmek de olanaksiz bir hale gelir.

Ekonomik Caydrncllk: Rakip firmalar; örgütün temel yeteneğini taklit edebilme gücüne sahip olduklart halde, taklit etme faaliyetinin ekonomik olarak çok fazla maliyet getirmesi nedeniyle bu fikirlerinden vazgeçerler. Ekonomik caydırıcılık nedeniyle, temel yeteneğin sürekliliği sağlanabilir.

İkame Edilemezlik: Bu nitelik, işletmede mevcut olan bir temel yeteneğin bir benzerinin olmamasını tarif eder. İkame edilemezlik niteliğinin en belirgin özelliği, işletmenin bu temel yeteneğinin öne çıkarlarak, alternatifler karşısında rekabetçi bir avantaj kazanılmasıdır. Kısacası bir işletmenin kaynak bazlı stratejisinin temelinde, örgütsel kaynaklarının heterojen olması ve kaynakların mobil olmaması yatmaktadır. Bu bağlılık, makalede adı geçen dört nitelik açısından işletmeye sürdürülebilir rekabetçi üstünlük sağlar. İşletmeyi diğerlerinden farklı kılan şey, kendisine has varlıkları ve yetenekleridir. Temel yetenek tabanlı stratejiler, bir işletmenin kendi varlık ve yeteneklerini detaylı bir şekilde incelemesine ve işletme kaynaklarını daha etkili bir şekilde kullanmasına olanak verir.

\subsubsection{Temel Yetenek Nitelikleri}

Temel yetenek ana bileşenleri; kaynaklar (resources), kabiliyetler (capabilities) ve yetenekler (competencies) şeklinde kategorize edilmektedir (Barney, 1991; Javidan,1998).

İşletme varlıkları denilince, örgüt tarafindan üretilen ürün ve hizmetlerde faydalanilan maddi/ maddi olmayan bütün hususlar akla gelir (Barney, 1991). Kabiliyetler, işletmenin varlikları kullanma derecesini tanımlar ve işletmenin işlevsel seviyelerinde uygulanır (Javidan, 1998, s.62). İşletme varlıklarını etkin bir iletişim vasıtasıyla kullanma ve hedeflere uyumlu aktiviteleri dönüştürebilme kapasitesine "yetenek" adı verilir. İşletmenin sahip olduğu yetenekler; fonksiyonel seviyelerde uygulanan kabiliyetlerin, stratejik iş birimleri (SBU) temelinde yaygınlaştırllmasıyla faydaya dönüşür. (Barney, 1991; Javidan, 1998). Temel yetenek ise, SBU'lar (Stratejik İş Birimleri) içinde uygulanan kabiliyetlerin etkileşimiyle meydana gelir.

Temel yeteneklerin ortaya çıkarılmasında iş birlikleri, bilgi, süreç etkileşimleri, ustalık, iletişim gibi hususlar oldukça önemlidir. Temel yeteneklerin meydana gelişi; bu yeteneklerin değerli olmasına, kıt bir şekilde bulunmasına, taklit edilememesine ve ikamesinin zor olmasına bağlidır. İşletmeye rekabet etme avantajı kazandırabilecek temel yeteneklerin tanımlanması için detaylı iç çevre analizlerinin yapılması gerekir. İşletmedeki temel yeteneklerin belirlenmesinde kullanılan metotlardan olan VRIN çatısı analizleriyle belirlenebilecek temel yeteneklerin, işletme dışı koşullara uyumlandırılması ile devamı sağlanabilir (Barney, 1991). Temel yeteneklerin sürdürülebilir olması için, yapının temel yeteneklerle ilişkili hale getirilmesi gereklidir. Aynı zamanda; temel yetenek temelli stratejilerin değişen çevre koşullarıyla uyumlu hale getirilmesi oldukça önemlidir. 


\subsubsection{Temel Yetenek Nitelikleri}

Temel yetenekleri olușturan bileșenler incelendiğinde, bu bileșenlerin birbirlerini hiyerarșik olarak bütünledikleri gözlenmektedir (Javidan, 1998, s.62). Bu hiyerarşi doğrultusunda gerçekleştirilecek analizler, işletmenin temel yeteneklerinin doğru bir şekilde belirlenmesine önemli katkılar sağlar.

Şekil 1'de verilen yetenek hiyerarşisinin en alt basamağında örgütsel kaynaklar bulunur. İşletme, örgütsel kaynaklarını kullanabilme durumuna göre hiyerarşide üst bir seviyeye yükselerek "kabiliyet" düzeyine ulaşır. Kabiliyetler, işletmedeki işlevsel düzeylerde gerçekleşir. Kabiliyetler, SBU içinde kullanıldıkça "yetenek" kavramı gündeme gelmeye başlar. Meydana gelen bu örgütsel yetenekler "değerll", " "nadir bulunur", "taklit edilemez" ve "ikame edilemez" nitelikteyse "temel yetenekler" kavramı gündeme gelir ve bu temel yetenekler işletmeye sürdürülebilir rekabet üstünlüğü kazandırır.

Temel yetenekler işletmenin bütününü kapsayan ve çalışanlar tarafından içselleştirilen yetenek havuzu özelliği taşır. Temel yetenekler, Şekil 1'de verilen hiyerarşik yapının en üst seviyesinde bulunduğundan, içinde işletmenin bütün kaynaklarını, kabiliyetlerini ve yeteneklerini içinde barındıırr (Javidan, 1998.s.62).

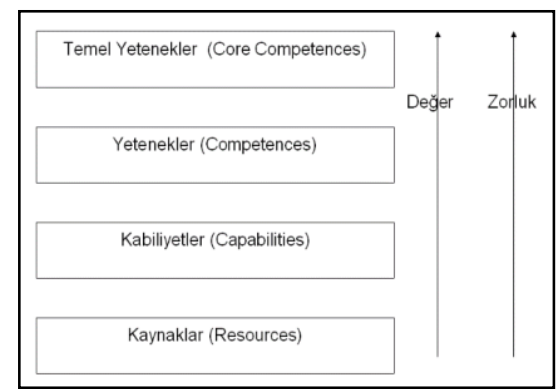

Şekil 1. Yetenek Hiyerarşisi (Javidan, 1998, s.62)

\section{Ar-Ge Performans1}

Araştırma ve geliştirme performansının istenilen doğrultuda ölçülmesi, teknoloji ve Ar-Ge yönetimi aktiviteleri için hayati bir öneme sahiptir. Araştırma ve geliştirme çalışmalarında karşılaşılan en önemli sıkıntıların başında, bu tip aktivitelerin geniş kapsamlı olması, yüksek maliyetli olması ve işletmeye olan getirisinin uzun bir döneme yayılması gelmektedir. Bu tip sorunların en aza indirilmesi ise, araştırma ve geliştirme yönetimi aktivitelerinin etkinliğine ve Ar-Ge’ye yönelik performans ölçümlerinin kalitesine bağlıdır. Araştırma ve geliştirme çalışmaları, niceliksel ve niteliksel değerlendirmelerle ölçülebilen aktivitelerden meydana gelmektedir. Araştırma ve geliştirme kapsamındaki temel araştırmaların performansının belirlenmesinde genelde nitel yöntemleri kullanmak daha uygun görünmektedir. Ürün geliştirme ve süreç iyileştirme aktivitelerinde ise nicel yöntemler daha fazla kullanıllır. Araştırma ve geliştirme aktivitelerinin genelde yüksek maliyetle yapılabilir olması, bu tip aktivitelerde performans değerlendirmelerinin sürekli bir şekilde yapılmasını gerektirir. Araştırma ve geliştirmeye yönelik performansin belirlenmesinde, temel performans kriterleri ortaya konulmakta ve araştırma ve geliştirme aktiviteleri bu kriterler temelinde ele alınmaktadır. Ar-Ge'ye yönelik performans kriterleri belirlenirken; kriterlerin ölçülebilir, detaylı, karşılaştırma yapılabilir, sürekli, sade, anlaşılabilir ve örgütün temel stratejileriyle uyumlu bir mantikla hazırlanmasina dikkat edilmelidir.

Araştırma-geliştirme performansının önemli göstergelerinden birisi, işletmenin patentleridir. Ar-Ge yapan işletmelerin patent başvurusu sayısı, işletmenin Ar-Ge performansı için önemli bir göstergedir. Günümüzde araştırma ve geliştirme aktivitelerine yeterli zamanı ayırabilen ülkelerdeki, patent başvuru sayılarının da oldukça fazla olduğu bilinmektedir (Kalça ve Atasoy, 2008). Yazında, araştırma ve geliştirme performans ölçümü birçok araştırmacı tarafindan değişik bakış açlarıyla gündeme getirilmiştir. Bahsi geçen çerçevede bütüncül bir ortak görüş bulunmamakla beraber, araştırma ve geliştirme yapan işletmelerdeki performans ölçümlerinde, işletmenin dış çevresini temel alan bir yaklaşımın ön planda bulunduğu dikkat çekmektedir (Ojanen ve Valua, 2003). Tablo 1'de, bu kapsamda gerçekleştirilen araştırmalar açıklamaları ile sunulmuştur: 
Tablo 1: Araştırma ve Geliştirme Performansına Yönelik Literatür Analizi

\begin{tabular}{|c|c|}
\hline Araştırmacilar & Açıklama \\
\hline $\begin{array}{c}\text { Brown ve Svenson } \\
(1988)\end{array}$ & $\begin{array}{l}\text { Yazarlar; sistemi girdiler, kabul edilen sistem, süreç içi ölçümler, sistem işletimi, çıktılar ve çıtıllar } \\
\text { şeklinde tasnif ederek, araştırma-geliştirme verimliliğini ölçmek amacıyla bir modelleme yapmıştır. }\end{array}$ \\
\hline Cordero (1990) & $\begin{array}{l}\text { Akademisyenler; metrikleri, teknik-ticari birim kaynakları, teknik ve pazarlanabilir çıtılar olarak } \\
\text { tasnifleyerek, inovasyon performansını ölçmek amacıyla bir model ve ölçüm sistemi } \\
\text { oluşturmuşlardır. }\end{array}$ \\
\hline $\begin{array}{l}\text { Brown ve Gobeli } \\
\qquad(1992)\end{array}$ & $\begin{array}{l}\mathrm{Bu} \text { araştırmada, araştırma ve geliştirmesüreçlerinin farklı aşamaları kapsamında tanımlayıcılar } \\
\text { ortaya konulmaktadır. Yazarlar araştırma ve geliştirme aktivitelerin hiyerarşik yapısı için } 3 \text { ana } \\
\text { düzey belirtmektedir. Bu düzeyler; bölümsel hedefler, projelerin yönetimi ve araştırma -geliştirme } \\
\text { aktiviteleri ile süreçlerdir. Ana düzeyler, ölçümleme yapmanın mümkün olduğu önemli aktiviteleri } \\
\text { kapsamaktadır. }\end{array}$ \\
\hline $\begin{array}{l}\text { Hultink ve Robben } \\
\text { (1995) }\end{array}$ & $\begin{array}{l}\text { Araştırma, Hollanda'da gerçekleştirilen anket uygulamasına ve literatür inceleme çalışması esasında } \\
\text { yapılmıştır. Sonuç olarak, ölçüm metrilerinin başarı ve başarısızlık durumlarını ortaya koymak için } \\
5 \text { temelsınıflandırma belirlenmiştir. Bu sınıflandırma; işletme faydasının ölçülmesi, araştırma ve } \\
\text { geliştirme programı seviyesindeki ölçümler, ürün seviyesindeki ölçümler, durum performansı ve } \\
\text { ürünün müşteri tarafından kabul edilmesi kapsamındaki ölçümlerdir. }\end{array}$ \\
\hline $\begin{array}{l}\text { Tipping ve } \\
\text { arkadaşları (1995) }\end{array}$ & $\begin{array}{l}\text { Araştırmacılar, teknoloji değer piramidi kullanarak, toplam } 165 \text { sanayi bünyesinde elde ettikleri } \\
\text { metrikleri değerlendirmeye tabi tutmaktadır. Toplam } 33 \text { temel ölçüm üzerinden, önemli olan ve } \\
\text { öncelikli bulunan onbir temel ölçüm seçilmiştir. }\end{array}$ \\
\hline $\begin{array}{l}\text { Schumann ve } \\
\text { diğgerleri (1995) }\end{array}$ & $\begin{array}{l}\text { Bu araştırma; süreç, insan, çıktı, iç ve diş müşteri ve toplumsal esaslardaki araştırma-geliştirme } \\
\text { süreçleri elementlerinitemel almakta ve kalite bazlı bir yapı önermektedir. }\end{array}$ \\
\hline $\begin{array}{l}\text { Ellis ve Curtis } \\
\quad(1995)\end{array}$ & $\begin{array}{l}\text { Bu çalışmada, çevrim süresi ve finansal performans ile eşleşen anket analizlerinden elde edilen } \\
\text { bulgular anlatılmaktadır. İnovasyon değer zincirinde bulunan üevrim zamanı ile müşteri çevrim } \\
\text { zamanı, araştırma-geliş̧tirme için harcanan süre ve pazar için ürün geliş̧irme çevrim süresi olarak } \\
\text { ifade edilmiştir. Araştrmadan elde edilen sonuçlar, çevrim zamanındaki finansal iyileştirmenin } \\
\text { önemli oranda azaldığını göstermiştir. }\end{array}$ \\
\hline $\begin{array}{l}\text { Cooper ve } \\
\text { Kleinschmidt } \\
(1996)\end{array}$ & $\begin{array}{l}161 \text { fonksiyonel birimin kıyaslanmasına yönelik araştırma, iş birimlerinin yeni ürün geliştirme } \\
\text { çabaların yüksek bir verimle nasıl olacağını gösteren on temel performans ölçümünü içermektedir. }\end{array}$ \\
\hline $\begin{array}{l}\text { Griffin ve Page } \\
\quad(1996)\end{array}$ & $\begin{array}{l}\text { Araştırma, proje seviyesindeki metrikleri müşteri bazlı metrikler, finansal ve teknik performans } \\
\text { başarısı olarak incelemektedir. Başarılı metriklerin kullanım ortalamaları bir projenin temel } \\
\text { stratejisine göre belirlenmektedir. }\end{array}$ \\
\hline $\begin{array}{l}\text { Leeve diğerleri } \\
\quad(1996)\end{array}$ & $\begin{array}{l}\text { Bu araştırma, araştırma-geliştirme sistem aşamalarındaki denetleme kriterlerini ve bu } \\
\text { denetlemelerin işleme alınmasıyla ilgili enformasyonu kapsamaktadır. Adı geçen araştırma- } \\
\text { geliştirme sistemi safhaları; girdiler, çıtıllar ve sonuçlardan meydana gelmektedir. Toplamda } 15 \\
\text { kriterlik bir metrik şeması, } 28 \text { sanayi işletmesindenalınan yanıtlar çerçevesinde ele alınmaktadır }\end{array}$ \\
\hline $\begin{array}{l}\text { Werner, B.M. ve } \\
\text { Souder, W.E. } \\
\text { 1997a. }\end{array}$ & $\begin{array}{l}\text { Yazarlar, Almanya ve Amerika'da bulunan işletmelerdekiaraştırma ve geliştirme uygulamalarını ele } \\
\text { aldıkları çalışmada, nicel çıkt metriklerin Amerika'da daha yaygın olarak kullanıldığını, aynı } \\
\text { zamanda Almanya'daki yöneticilerin araştırma ve geliştirmeye yönelik metriklerde daha basit olan } \\
\text { girdi ölçümleri tercih ettiklerini göstermektedir. Araştırma, ülke ve endüstri bazındaki temel } \\
\text { metrikleri de raporlamaktadır. Ele alınan sanayiiler: danışmanlık, petrol otomotiv, havacıllı, } \\
\text { madencilik, kimya, elektronik, kimyasallar ve telekomünikasyon sektörlerini içermektedir. }\end{array}$ \\
\hline $\begin{array}{l}\text { Meyer ve diğerleri } \\
\text { (1997) }\end{array}$ & $\begin{array}{l}\text { Yazarlar, araştırma ve geliştire performansına yönelikmetrikler için etkinlik ve verimlilik temelli bir } \\
\text { platform önermektedir. Bu çerçevede, üürünlerin ekonomik yararı, geliştirme maliyetine kıyasla } \\
\text { üründen elde edilen gelirler gibi nicel verileriiçermektedir. }\end{array}$ \\
\hline $\begin{array}{c}\text { Hauser ve } \\
\text { Zettelmeyer (1997) }\end{array}$ & 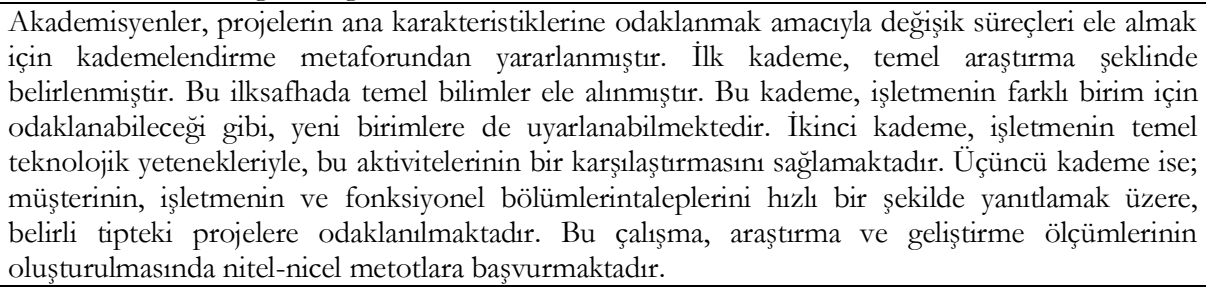 \\
\hline $\begin{array}{l}\text { Kerssens-van } \\
\text { Drongelen ve } \\
\text { Bilderbeek (1999) }\end{array}$ & $\begin{array}{l}\text { Yazar tarafindan ortaya konulan yapı, bir araştırma-geliştirmebölümü ile ortalama bir araştırma- } \\
\text { geliştirme bölümünün performansını karşılaştırmalı olarak incelemektedir. Bu açıdan, on temel } \\
\text { araştırma-geliştirme faaliyeti, 6'lı bir sakalada ele alınarak değerlendirilmektedir. Elde edilen } \\
\text { ortalama sonuçlar, gerçek dünya örnekleriyle karşlaştırmalı olarak ele alınmaktadır. }\end{array}$ \\
\hline $\begin{array}{l}\text { Driva ve diğerleri } \\
\qquad(2000)\end{array}$ & $\begin{array}{l}\text { Bu araştırma kapsamında, uygulayıcıların ve akademisyenlerin ölçüm önerileri arasındaki temel } \\
\text { yaklaşım farklılıkları ele alınmıştır. İşletmeler, zaman, maliyet ve kalite ile ilgili metrikleri önerirken; } \\
\text { akademisyenler, daha çok tasarım ve geliştirme safhalarındaki müşteri temelli kullanım metriklerine } \\
\text { ihtiyaç duymaktadır. }\end{array}$ \\
\hline
\end{tabular}




\begin{tabular}{|c|c|}
\hline Kim ve Oh (2002) & $\begin{array}{l}\text { Bu araştırmadaki tasnifleme, Kore'deki araştırma ve geliştirme performans metrik sistemlerini } \\
\text { içeren bir anket uygulamasıyla, araştırma ve geliştirme tipleri esasında gerçekleştirilmiştir. Meydana } \\
\text { getirilen araştırma ve geliştirme tipleri, temel araştırma-geliştirme, uygulamalı araştırma-geliştirme } \\
\text { ve ticari araştırma-geliştirme olarak ortaya konulmuştur. }\end{array}$ \\
\hline $\begin{array}{l}\text { Bremser ve Barsky } \\
\text { (2004) }\end{array}$ & $\begin{array}{l}\text { Bu araştırma, araştırma-geliştirme performans metriklerinde kurumsal karne pratiklerine vurgu } \\
\text { yapmaktadır. }\end{array}$ \\
\hline $\begin{array}{l}\text { Fey ve Birkinshaw } \\
\text { (2005) }\end{array}$ & $\begin{array}{l}\text { Bu araştırma, araştırma ve geliştirme faaliyetlerininnin yönetim modunun belirlenmesinin, yeni } \\
\text { fikirlere açılık ve bilginin kodlanması bakışından, araştırma-geliştirme performansına hangi } \\
\text { etkilerinin olabileceğini incelemektedir. }\end{array}$ \\
\hline $\begin{array}{l}\text { Chiesa ve diğerleri } \\
\text { (2007) }\end{array}$ & $\begin{array}{l}\mathrm{Bu} \text { araştırma, araştırma ve geliştirme aktiviteleri için performans metrikleri sisteminin } \\
\text { tasarlanmasındaki sorunlara değinmektedir. }\end{array}$ \\
\hline $\begin{array}{c}\text { Asakawa ve } \\
\text { diğerleri (2010) }\end{array}$ & $\begin{array}{l}\mathrm{Bu} \text { araştırma; laboratuvarlardaki açık inovasyon politikalarının, laboratuvarlar arasındaki dış } \\
\text { iletişimlerle Ar-Ge performansının nasıl etkilenebileceğini araştırmıştır. }\end{array}$ \\
\hline $\begin{array}{l}\text { Lazzarotti ve } \\
\text { diğerleri (2011) }\end{array}$ & $\begin{array}{l}\text { Bu makalede, araştırma-gelişmeye yönelik performans ölçümü kapsamında kurumsal karne bazlı } \\
\text { bir bakış açısı ele alınmaktadır. }\end{array}$ \\
\hline $\begin{array}{l}\text { Hung ve diğerleri } \\
\text { (2013) }\end{array}$ & $\begin{array}{l}\mathrm{Bu} \text { makalede, gruplardaki iletişim yöntemleriyle akademik araştırma-geliştirme performans1 } \\
\text { arasındaki ilişkiler ele alınmıştır }\end{array}$ \\
\hline Martin (2016) & $\begin{array}{l}\text { Bu makale, araştırma-geliş̧tirme ve inovasyon politikalarına yönelik enstrumanları esas alan } \\
\text { literatürü incelemekte ve öneriler vermektedir. }\end{array}$ \\
\hline
\end{tabular}

\subsection{Teknoloji Değer Piramidi}

Teknoloji Değer Piramidi (TDP), araştırma ve geliştirme yapan işletmelerin performansını değerlendirmek için gerekli olan metrikleri hiyerarşik açılan inceleyen ve araştırma-geliştirme performans metrikleri çerçevesinde oldukça anlaşlır temel sunan bir modeldir. Bu model ilk defa Tipping ve arkadaşları (1995) tarafindan oluşturulmuş ve teknoloji yönetimi alanında oldukça fazla kabul görerek, araşırma-geliştirme faaliyetlerinin yönetiminde temel bir yaklaşım olarak benimsenmiştir. Teknoloji Değer Piramidi modeli, araştırma-geliştirme yapan örgütlerin performansını ortaya koymak için, yukarıdan aşağıya ve çıktılar temelli bir yaklaşım önermekte ve içinde barındırdığ metriklerle araştırma-geliştirme yapan örgütlerin kendilerini geliştirmek için ihtiyaç duyabilecekleri metrikleri belirleme olanağı sunmaktadır (Bremser ve Barsky, 2004). Bu model esasında; 5 temel hiyerarşik sinıflandırma yapilmış olup, sınıflandırma: "Değer Yaratma", "Portföy Değerlendirmesi”, "İş ile Bütünleşme”, "Teknolojinin Varlıksal Değeri" ve "Yeniliğe Destek Veren Ar-Ge Süreçleri Pratikleri”" olarak belirlenmiştir. Bu sınıflandırma, bir örgütün araşturma-geliştirme performansının belirlenerek iyileştirilmesinde önemli bir araç niteliğindedir. Değer Yaratma: İşletmenin teknoloji geliştirmeye yönelik çalışmalarının, işletmenin büyümesi ve fayda sağlamayı sürdürmesi esasındaki değeriyle ilgilidir.

Portföy Değerlendirme: Araştırma ve geliştirme programının zamanlama, risk, yetenek ve aktiviteler le bağlantısına ve araştırma ve geliştirme portföyünün doğru olarak ortaya konulmasına imkân sağlar.

İsle Entegrasyon: Yapılan aktivitelerin stratejiyle uyumlu olmasını, teknolojinin üretime transfer edilmesini ve çapraz ekipler şeklinde çalışmayı anlatır.

Teknolojinin Varllksal Değeri: İsletmede mevcut olan teknolojinin varlıksal değerini ortaya koyar.

Inovasyona Destek Veren Araștırma-Gelistirme Süreç Uygulamalar: Araştırma ve geliştirme süreçlerinin işletmeye fayda verecek çlktılar üretmesini anlatır. Bu kategori, araştırma ve geliştirme aktivitelerindeki çalışan kalitesi, proje yönetimi ve liderlik müşteri memnuniyeti gibi hususlardaki pratikleri inceler (Tipping vd., 1995).

\section{Temel Yetenek Tabanlı Yaklaşımların Ar-Ge Performansı ile İlişkisi: Yönetişim Modeli Önerisi}

Ar-Ge performansı belirleme çalışmalarının, genellikle işletmelerin finansal ve altyapı yatıımlarına odaklandığ1 ve temel yetenekleri çok fazla dikkate almadığı görülmektedir. Aynı zamanda, Ar-Ge performansına yönelik ölçümlerin büyük bir bölümünün örgüt seviyesindeki verileri kapsadığı ve örgütler arası değerlendirmeler için fazla bir içerik sağlamadığı gözlenmektedir. Oysa OECD tarafindan yayınlanan raporlarda en fazla önemsenen hususlardan birisi, 2011 yllından beri gündemde olan "Ar-Ge Yönetimi Ekosistemi”" yaklaşımıdır. Adı geçen ekosistem yaklaşımı, Ar-Ge yapan işletmeler için temel yetenek tabanlı yaklaşımların önemini hatırlatmakla birlikte, özel sektör ile girişimcileri merkeze koymakta ve araştırmageliştirme faaliyetlerinin yönetiminde devlet dışındaki aktörlerin de aktif olarak yer alması gerektiğine vurgu 
yapmaktadır. Bir Ar-Ge örgütünün performansının, içinde bulunduğu ekosistem dikkate alınarak ölçülmesi oldukça önemlidir. Ulusal Ar-Ge performansında önemli atılımlar sağlayabilmek için; örgütsel performans belirlenirken, teknokent toplulukları içinde yer alan diğer örgütlerin bütünleşik performanslarını da işin içine katmak ve ekosistem içindeki diğer aktörlerin katkılarını da dikkate almak uygun olacaktır.

\subsection{Ar-Ge Yönetiminden Ar-Ge Yönetişimi’ne Doğru...}

Son yıllarda çoğunlukla gündeme gelen "Ar-Ge Yönetimi Ekosistemi” mantı̆̆ı araştırma ve geliştirme politikaları için Ar-Ge Yönetimi’nden, Ar-Ge Yönetişimi'ne doğru bir geçiş sağlanmasına dikkat çekmektedir. Yönetişim ve yönetim kavramları birlikte incelendiğinde; kamu yönetimi bakış açısıyla özel sektör yönetim yaklaşımını bir araya gelmesi, kamu ve özel sektör arasındaki belirsizlik durumların minimuma indirilmesi ve birçok sistem için yeniden yapılandırmaya imkân vermesine yönelik konular gündeme gelmektedir. Yönetim konusu daha çok organizasyonel bir seviyeyi anlatırken, yönetişimde örgütler arası bir yaklaşım hissedilir. Yönetişim olgusu, kamu ve özel sektör gibi temel aktörleri birer ortak gibi kabul etmekte ve ileri düzey bir yönetimin ancak bu ortakların sistemli ve stratejik iletişimden oluşan bir yönetme ve denetleme mekanizmasıyla mümkün olabileceğini savunur (Özer, 2006, s.60). Ar-Ge Ekosistemi mantığı ise, özellikle teknokentlerde gerçekleșen Ar-Ge aktiviteleri için değişik stratejilerin olușturulabileceği bir Ar-Ge yönetişimi mantığını akla getirmektedir. Bu konu, hali hazırdaki Ar-Ge politikalarında önemli iyileştirmeleri sağlayabilecek ve teknokent toplulukları için Ar-Ge'ye yönelik performans belirleme araştırmalarını örgütsel bir seviyeden örgütler arası seviyeye çekebilecektir. $\mathrm{Bu}$ kapsamda stratejik pratiklerin kaynak temelli bir bakışla temel yetenek temelli stratejilerden yararlanılarak yapılabileceği değerlendirilmektedir. Çünkü teknokentlerde olduğu şekilde birbirine benzer aktiviteleri yapan işletmelerin sahip olduğu yeteneklerin, teknokentler içindeki değişik işletmelerde ortak şekilde bulunma olasıllğı oldukça yüksek görünmektedir. Teknokent toplulukları içindeki işletmelerin ortak ve öncelikli temel yeteneklerinin analiz edilerek, ortak havuzlarda ve Ar-Ge yönetişimi yaklaşımıyla yönetilmesi, ele alınan teknokent topluluğunda oldukça yüksek bir sinerjiye ve performansa vesile olabilir. Teknokentlerde uygulanabilecek temel yetenek temelli yaklaşım sayesinde işletmelerde ortak ve öncelikli olan kabiliyet, yetenek ve temel yeteneklerin ortaya konulması ve Ar-Ge örgütleri için ortak ve öncelikli temel yetenek envanterinin meydana getirilmesi mümkündür. Bu şekilde, işletmelerin temel yeteneklerinin Ar-Ge performansına etkisinin kuramsal bir çerçevede analiz edilebileceği ve kaynak bazlı analizlerle işletmelerden bağımsız temel yetenek havuzlarının oluşturularak, Ar-Ge performansında hızlı ve ani ilerlemelerin sağlanabileceği değerlendirilmektedir. Anlattlan hususları şematize eden bir model Şekil 2'de verilmiştir:

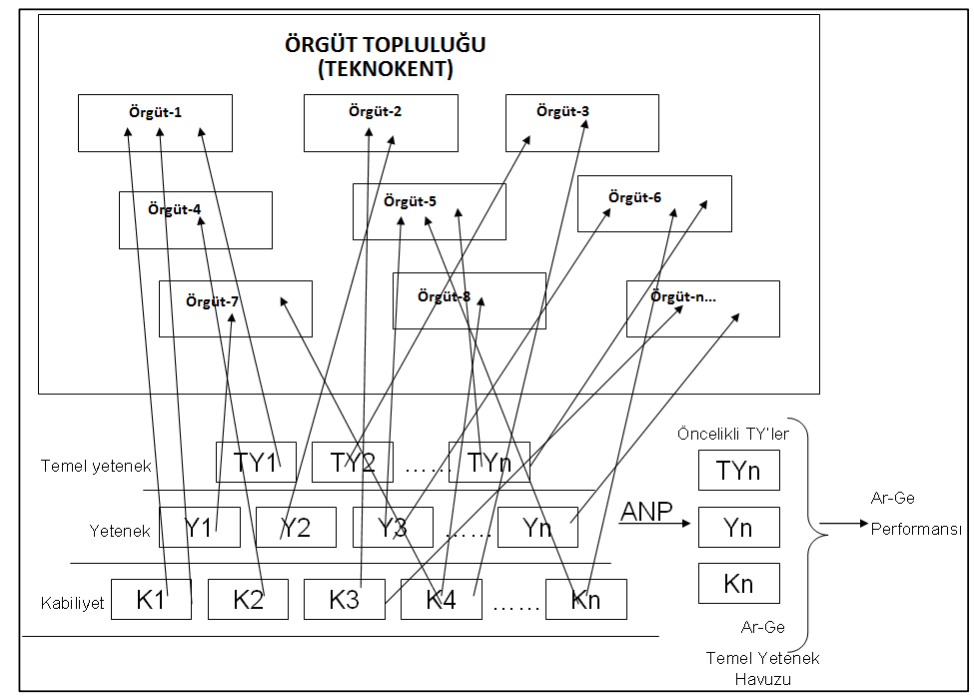

Şekil 2. Temel Yetenek Tabanlı Ar-Ge Yönetimi Modeli (Teknokent Düzeyi) 
Şekil 2'de bir TGB'de (Teknoloji Geliştirme Bölgesi) bulunan Ar-Ge işletmelerinin; kabiliyet, yetenek ve temel yeteneklerinin ortaya konulması, ANP (Analitik Ağ Süreci) yöntemi ile öncelikli ve ortak olan kabiliyetlerinden, yeteneklerinden ve temel yeteneklerinden oluşan bir temel yetenek havuzunun (envanterinin) meydana getirilmesi ve temel yetenek havuzu ile Ar-Ge'ye yönelik performans ilişkisine yönelik bir model sunulmuştur.

Şekil 2'deki Ar-Ge yönetimi modeli doğrultusunda; öncelikli ve ortak temel yeteneklerin analiz edilerek tanımlanması ile, her bir teknokent için meydana getirilebilecek temel yetenek havuzlarının, sonrasında teknokentler arası bir düzeye çekilerek Ar-Ge politikalarının temel yetenek bazlı bir stratejiyle güncellenmesine olanak sağlayabilecek biçimde tasarlanabileceği ve etkili bir Ar-Ge yönetişimi için temel olabilecek bu öneriyle, ulusal Ar-Ge performansında önemli ilerlemelerin yaşanabileceği değerlendirilmektedir.

MÜSİAD'ın 2012 yilında yayınladığı raporlarında yayınlanan ve küresel rekabet kapsamında Ar-Ge ve inovasyon açısından belirlenebilecek stratejiler kapsamında ifade edilen "yetenek havuzlant kalitesi” olgusu, yenilik için gereken temel zorunluluklardan birisi olarak gündeme getirilmiştir. Ar-Ge performansını üst seviyelere çekebilmek için oluşturulabilecek yetenek havuzları, Ar-Ge işletmeleri arasında üst seviyede bir entegrasyon sağlayabilir. Böylece; mevcut Ar-Ge politikaları bağlamında gerçekleștirilen Ar-Ge yönetimi çalışmaları, işletmelerin temel yeteneklerini ve bütünleşmeyi esas alan bir Ar-Ge yönetişimi mantığı ile daha etkili bir iyileştirilebilir. Önerilen modelin özel sektör ve kamu arasındaki bütünleşmeyi destekleyeceği, işletmelerin birbirleriyle iletişimini güçlendireceği, devlet tarafindan yapılan Ar-Ge yatırımlarını daha verimli hale getireceği, Ar- Ge işletmelerindeki çalışanların motivasyonuna olumlu etkiler sağlayabileceği, üniversite-sanayi iş birliği çerçevesinde gerçekleşecek eğitim ihtiyaçlarını destekleyerek bu iş birliğine katkılar vereceği değerlendirilmektedir.

Şekil 3’te, yukarıda önerilen ekosistem modeli teknokent toplulukları seviyesine çekilerek şematize edilmiştir:

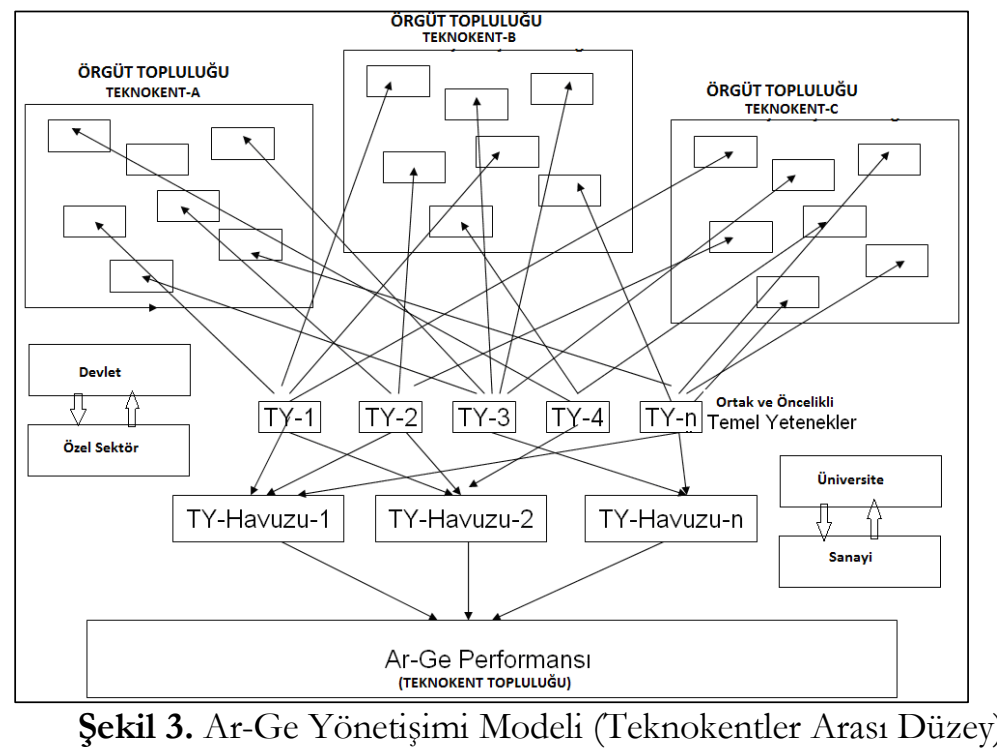

Şekil 3'de verilen Ar-Ge Yönetişimi Modeli, çok sayıda teknokent topluluğunu esas almakta, önerilen ilişkiler temelinde üniversite-sanayi işbirliğine vurgu yapmakta ve her bir teknokentte mevcut olan temel yetenekleri (TY-1, TY-2, TY-3, ... TY-n) ortaya koymak ve her bir temel yetenek için ayrı bir Temel Yetenek Havuzu oluşturmaktan (TY-Havuzu-1, TY Havuzu-2, TY Havuzu-3......, TY Havuzu-n) bahsetmektedir. Teknokentler arası seviyedeki temel yetenek havuzlarında bulunacak ileri teknoloji kaynakları ve yetkin Ar-Ge personeli sayesinde; üniversite-sanayi iş birliğinin desteğiyle, Ar-Ge performansında ani ve önemli ilerlemeler sağlayabilecek Ar-Ge projeleri geliştirebileceği düşünülmektedir. Şekil 3' de verilen modelde, bir önceki modelde ifade edilen altyapı aynı şekilde benimsenmekte ve 
teknokent toplulukları çerçevesinde temel yetenek tabanlı bir entegrasyon sisteminin inşa edilmesi önerilmektedir. Bu kapsamda, öncelikli ve ortak temel yetenek tanımlama faaliyetleri tamamlandıktan sonra, temel yetenek havuzları oluşturulabilir. Böylece teknokentler arasındaki entegrasyon sorunlarının minimuma indirebilmesi ve temel yetenekler envanterinin oluşturulabilmesi mümkün olabilir. Bu tip stratejik bir kurgu içinde gerçekleştirilecek Ar-Ge projelerinin, ulusal Ar-Ge performansına hissedilir derecede katkılar sağlaması mümkündür. Bahsedilen Ar-Ge ekosistemi yaklaşımının doğru bir şekilde oluşturulabilmesi, firmalarda bulunan temel yetenek niteliklerinin sağlıklı bir şekilde belirlenmesine bağlıdır. Önerilen stratejik modelin, üniversite-sanayi iş birliğinin sağlanmasıyla önemli bir ilişkisinin olduğu düşünülmektedir. Önerilen model çerçevesinde, mevcut Ar-Ge yönetimi faaliyetlerine yönelik önemli iyileştirmeler gerçekleştirilebilir. Adı geçen modelin geçerliliği aşağıdaki adımlar esasında sağlanabilir:

- Veri toplama için uygun coğrafi bölgenin ve teknokent topluluğunun seçimi

- Teknokent topluluğu içindeki işletmelerin temel yetenek niteliklerinin belirlenmesi,

- Teknokent topluluğu içindeki işletmelerin ortak ve öncelikli temel yeteneklerinin ve temel yetenek niteliklerinin belirlenmesi,

- Teknokent topluluğu içindeki işletmelerin ortak ve öncelikli temel yeteneklerinin toplam Ar-Ge performansıyla ilişkisinin belirlenmesi

- Teknokent topluluğunun ortak ve öncelikli temel yeteneklerine ilişkin niteliklerinin Ar-Ge performansina etkisinin ortaya konulması.

Ar-Ge yönetimi performansını belirlemeye yönelik iyileştirme çalışmalarının, kuramsal altyapısı yüksek bir Ar-Ge yönetişimi mekanizması ile gerçekleştirilebileceği ve önerilen Ar-Ge yönetişim modeli ile Ar-Ge performansında önemli ilerlemeler sağlanabileceği değerlendirilmektedir. Bu çalışma, temel yetenek tabanlı bir Ar-Ge yönetişimi modeliyle, Ar-Ge yönetimi performansının yükseltilmesine yönelik öngörüleri desteklemeyi amaçlamıştır. Araştırmanın esas amacı, önerilen Ar-Ge yönetişimi modelini yaklaşımını destekleyebilecek ve bu konuda gelecekte yapılabilecek görgül araştırmalar için temel ortaya koymaktır. Bahsedilen bu yaklaşım çerçevesinde, araştırmanın ana önermesi aşağıdaki şekilde belirlenmiştir:

Önerme: Teknokent topluluklan bünyesinde Ar-Ge faaliyeti gerçelelestiren ișletmelerin ortak ve öncelikli temel yeteneklerinin ortaya koyulmast ve bu temel yeteneklerin üniversite-sanayi is birliğ cerçevesinde entegre bir șekilde yönetilmesi, teknokentler Ar-Ge yönetisimi yaklasıımm benimsenmesini sağlayarak, işsletmelerin Ar-Ge performanslarnda önemli ilerlemelere ve ani sicramalara neden olabilir.

\section{Sonuç}

$\mathrm{Bu}$ çalışma; Ar-Ge işletmelerinin performansını ölçmeye yönelik politikaların, temel yetenekleri merkeze alan bir çerçevede iyileştirilmesine yönelik bir model oluşturmayı amaçlamıştır. Bu amaç doğrultusunda; kaynak tabanlı kuram esas alınarak, Ar-Ge işletmelerinin ortak ve öncelikli temel yeteneklerinin Ar-Ge performansıyla nasıl ilişkilendirilebileceği tartışlmıştır. Araştırmada öncelikli olarak Ar-Ge örgütlerinin içyapılarına yönelik stratejik yaklaşımlar incelenmiştir. Aynı zamanda yönetim ve strateji yazınında Ar-Ge performansına yönelik araştırmalar kapsamında yazın taramaları yapılmıştır. Ardından, belirlenen kuramsal çerçeve temelinde temel yetenek tabanlı stratejilerin Ar-Ge performansıyla nasıl ilişkilendirilebileceğini gösteren model ortaya konulmuştur.

Ar-Ge işletmelerini rakipleri karşısında başarıya ulaştıracak en önemli faktör; içinde bulundukları örgütsel toplulukla yüksek düzeyde bir bütünleşme sağlayarak, teknolojiye, bilgiye ve temel yeteneklere dayalı çalışmalar ortaya koymalarıdır. Bu entegrasyonun etkili bir şekilde sağlanabilmesi, mevcut Ar-Ge politikalarının kaynak tabanlı yaklaşımlar temelinde iyileştirilmesine bağlıdır. Ar-Ge işletmeleri için belirlenen temel politikalar, işletmelerde mevcut olan temel yetenekleri stratejik bir değere dönüştürebilmelerine imkân verecek biçimde ele alınabilir. Araştırma ve geliştirme yapan işletmeleri, insanlığa ve topluma katkı verecek yenilikleri üretecek bir olgunluk düzeyine getirebilmek için; temel yetenek bazlı bir Ar-Ge yönetimine geçilmesinin uygun olacağı değerlendirilmiştir. Araştırma kapsamında; bahsedilen bu yaklaşımları desteklemek amaciyla, teknokent seviyesinde (Şekil 2) ve teknokentler arası seviyede yönetişim modeli (Şekil 3) önerileri geliştirilmiştir. Şekil 3’ de önerilen temel yetenek tabanlı Ar- 
Ge yönetişimi yaklaşımıyla, teknokent topluluklarında bulunan işletmelerin performansının, kaynak ve yetenek tabanlı stratejilerle, örgütler arası bir seviyede yönetilmesine ilişkin sistematik bir yapı önerilmiştir. Bahsi geçen yaklaşımın Ar-Ge yönetimi politikalarına aktarılmasının; kaynak temelli performans sistemine geçişe imkan vereceği, kamu, özel sektör ile üniversite arasında Ar-Ge açısından sağlanması gereken entegrasyona katkıda bulunabileceği, teknokent toplulukları içinde yer alan işletmelerin birbirleriyle iletişimini kuvvetlendireceği, Ar-Ge yatırımlarını daha görünür kılabileceği ve önerilen sistemin yetkin beyin gücünün performansında ve motivasyonunda önemli iyileştirmelere neden olabileceği varsayılmaktadır. Önerilen modellerin teknokent yönetimleri tarafından dikkate alınması halinde; teknokent topluluklarındaki entegrasyon ve performans sorunlarının azaltrlabilmesi mümkün olabilecektir. Aynı zamanda bu modelin; Ar-Ge işletmelerinin sahip olduğu nitelikli teknolojik kaynakların ve yetkin beyin gücünün bütünleşik bir şekilde kullanılmasına imkân sağlaması nedeniyle, teknokent topluluklanı içinde faaliyet gösteren örgütlerin Ar-Ge performanslarında önemli artışlar sağlayabileceği değerlendirilmiştir.

Ar-Ge işletmeleri arasında yaşanan entegrasyon sorunlarını öncelikli olarak dikkate almak oldukça önemlidir. Teknokentler genelde birbirlerinden bağımsız olarak yönetilmesi sebebiyle oluşan bütünleştirme problemlerinin, Ar-Ge yönetimi performansına olumsuz etkileri bulunmaktadır. Ar-Ge işletmelerini birbirlerine yaklaştırarak, bütünleşik bir şekilde yönetilmesine olanak verecek stratejiler geliştirmek gereklidir. Ar-Ge performansını etkileyen en temel faktörlerin nitelikli beyin gücü ve işletmelerde bulunan ileri teknolojik kaynaklar olduğu düşünüldüğünde, işletmelerin temel yeteneklerinin entegre edilerek yönetilmesi, Ar-Ge performansının arttırılması amacına ulaşmak için atılabilecek uygun bir adımdır. Ar-Ge işletmeleri arasında yaşanan bütünleşme problemleri, iletişime ve birlikte çalışmaya imkân verecek stratejik bir yaklaşımın olamamasından kaynaklanmaktadır. Ar-Ge işletmelerinin örgüt yapısının diğer yapılarla kıyaslandığında önemli farklılıklar göstermesi sebebiyle, bahsedilen anlayışın kuramsal temelde ve insanı esas alan kaynak temelli bir bakışla değerlendirilmesi oldukça önemlidir.

Drucker'e (1996) göre Ar-Ge, teknolojiye veya ticarete yönelik stratejilerle geliştirilmelidir. Ar-Ge yönetimi stratejisinin sadece üretilen teknolojinin toplumsal katkısını dikkate alması durumunda, ticari pazardan bağımsız bir Ar-Ge çalışması söz konusu olacaktır. Ar-Ge yönetimi stratejilerinin belirlenmesi sırasında, sadece teknolojiye odaklanmak da çok doğru bir yaklaşım değildir. Yenilikçi ürünler geliştirebilmek için, üretilen teknolojinin ticarileştirilebilme yeteneğine de büyük önem vermek gereklidir. Ar-Ge yönetimi stratejisi sadece ticarete yönelik olarak belirlendiğinde ise, yenilikçi ürünün yalnızca müşteri ihtiyaçlanı doğrultusunda üretilmesi nedeniyle toplumsal katkının saf dışı bırakılma riski söz konusudur (Drucker, 1996). Ticari amaçlara yönelik bir strateji, yenilikçi ürün üretiminin olmazsa olmaz bir koşulu olmakla beraber, toplumsal katkı ve insanlık için fayda sağlama olgusu hiçbir zaman göz ardı edilmemelidir. Bununla birlikte; örgütün yeteneklerini dikkate almadan, sadece ticari veya teknolojik odağa bağlı kalınarak gerçekleştirilen Ar-Ge faaliyetlerinden hiçbir zaman istenen sonuçların alınamayacağı açıktır. Bu durumun, Ar-Ge politikalarının iyileştirilmesine yönelik çalışmalar sırasında dikkatle ele alınması gereklidir. Günümüzdeki Ar-Ge işletmelerinin çok büyük bir kısmı sahip oldukları temel yeteneklerin farkında bile değildir. Teknokentlerde faaliyet gösteren Ar-Ge işletmelerinin ortak ve öncelikli kabiliyet, yetenek ve temel yeteneklerinin belirlenmesi, işletmelerin Ar-Ge performansını çok daha ileri düzeylere taşıyabilir. Ar-Ge işletmelerine yönelik stratejikler, örgütlerdeki temel yetenekleri stratejik imkanlara dönüştürebilecek bir yapıda kurgulanmalıdır. Ar-Ge işletmelerini ileri düzey bir olgunluk seviyesine ulaştırabileceği düşünülen bu yaklaşımları ulusal bir boyuta taşımak için; ekosistem mantığına dayalı bir ArGe yönetimi sistemine geçilmesi uygun görünmektedir. Ar-Ge yönetiminde başarı sağlamak için; örgütsel kaynakları uygun şekilde kullanma becerisine sahip olmak, bu beceriler sonucunda meydana gelen kabiliyetleri iş birimlerine sistematik olarak yaymak ve müşteri için değer taşıyan, kıt, taklidi ve ikamesi zor olan temel yetenekleri belirleyerek kurumsal stratejik yapılara uygun bilinçli yaklaşımlar geliştirilmesi gereklidir. Kaynak tabanlı kuram ve temel yetenek tabanlı stratejiler temelinde geliştirilecek bu yaklaşımların, ilgili tüm aktörleri içinde barındıran bir Ar-Ge ekosistem içinde düşünülmesi, Ar-Ge performansının arttırılması önemli katkılar verecektir.

Ar-Ge politikaları bağlamında ele alınabilecek öncelikli iyileștirmelerin; Ar-Ge yönetiminde kaynak tabanlı yaklaşımların eksikliği, Ar-Ge performansının belirlenmesindeki kuramsal-yöntemsel sorunlar ve 
Ar-Ge işletmelerindeki entegrasyon sorunlanı üzerinde yoğunlaştırllması uygun görünmektedir. Ar-Ge işletmelerinde mevcut olan stratejilerin, genelde diş çevreyi esas alması ve performans değerlendirmelerinde iç çevre analizlerinden kısıtlı bir şekilde yararlanılması, işletmelerdeki ileri teknolojik kaynakların ve yetkin beyin gücünün performans değerlendirmeleri için fazlaca dikkate alınmamasına sebep vermektedir. Oysa Ar-Ge performans1, bu tip işletmelerde görev yapan personelde mevcut olan beyin gücünün örgütün temel yetenekleri haline gelmesinden büyük oranda etkilenmektedir. Temel yeteneklerin bütünleşik bir şekilde ele alınarak ulusal Ar-Ge politikalarına doğru bir şekilde yansıtılması halinde, ulusal Ar-Ge performansında önemli ilerlemeler sağlanabilir. Bu bakış açısı çerçevesinde ele alınması önerilen yaklaşımların ulusal araştırma ve geliştirme politikalarına yansıtıllmasının, performansın arttırılması açısından önem taşıdığı düşünülmektedir.

Yönetim ve örgüt alanında yapılan araştırmaların kuramsal açıdan literatüre katkısı iki temel boyut çerçevesinde değerlendirilebilmektedir (Corley ve Gioia, 2011, s.15). Bu boyutlar, çalışmanın özgünlüğüne (artımsal veya açıklayıcı) ve yararlılı̆ı̆na (pratik veya bilimsel olmasına) yönelik yaklaşımlardır. Bu çalışmanın özgünlüğünün, teknokent yönetimlerine yönelik katkılanı açıklayıcı bir bakış açısından tanımlamasından ve bu konuda daha önce önerilen modellerden farklı olarak uygulamaya yönelik nitelikler içermesinden kaynakladığı düşünülmektedir. Çalışmanın yararlılığı noktasında ise; bilimsel bir yararlılıktan ziyade, daha çok uygulama noktasında bir yararll1ık söz konusudur.

Teknokent yönetimleri olarak adlandırılan yönetsel mekanizmaların, kaynak tabanlı yaklaşımlar açısından yeniden ele alınarak, teknokentler arası entegrasyonu arttıracak politikalar ve uygulamalar eşliğinde yeni bir Ar-Ge Yönetişimi Modeli'ne doğru evrilmesi gereklidir. Bu araştırma kapsamında adı geçen modelin uygulamaya alınmasi; Ar-Ge ekosistemi olarak tanımlanan yapı için yeni açılımlar getirebilir ve Ar-Ge politikalarında orta vadede yapılabilecek iyileştirmeler için kuramsal ve uygulamalı bir altyapı sağlayabilir. Ar-Ge ekosistemi yaklaşımı, ancak bu aktörlerin bir arada ve belirli stratejiler temelinde entegre olarak yönetilmesi sonucu daha verimli hale gelebilir. Teknokentler topluluklarnnda muhtemelen dağınık bir halde sürdürülen Ar-Ge faaliyetlerinin koordinasyonunu güçlendirebilecek bir mekanizma olarak değerlendirilebilecek yetenek havuzlarının oluşturulması, işletmelerin entegrasyonunda motive edici bir güç olabilir. Bu havuzlar; öncelikli ve ulusal nitelikli kritik Ar-Ge projelerini tamamlamaya yönelik yapılar olarak görev yapabileceği gibi, farklı Ar-Ge projelerini birleştiren nitelikli çalışma alanları şeklinde de düşünülebilir. Sonuç olarak; yüksek nitelikli araştırma ortamlarının kamu-özel sektör ve üniversite iş birliğiyle tesis edilmesi, kaynak tabanlı Ar-Ge yönetişimi mantığını önemli ölçüde güçlendirebilecektir. Bu öneriler 1şı̆̆ında gelecek dönemlerde gerçekleştirilebilecek uygulamalar ile, Ar-Ge işletmelerinde mevcut olan kaynaklardan çok daha etkin bir şekilde yararlanma imkânı doğabilecek ve âtıl durumda olan birçok yüksek teknolojinin üretime dahil olması sağlanabilecek ve ulusal anlamda büyük önem taşıyan fakat entegrasyon ve kaynak sorunları nedeniyle sonuçlandırılamayan yüksek nitelikli birçok Ar-Ge projesinin etkili bir şekilde tamamlanması mümkün olabilecektir.

\section{Extended Abstract}

R\&D studies are one of the most important activities that should enable the advancement of humanity and realization of social innovations. R\&D organizations are among the types of organizations that take responsibility to research and develop technological innovations for appropriate markets (Abbey \& Dickson, 1983). According to Yaylalı et al. (2010), R\&D activities represent a high value-added transformation process in which knowledge becomes concrete products. R\&D studies are carried out within the business communities called Technopark, where the infrastructure and investments required for the formation of scientific and technical knowledge are provided. It seems possible to reach extraordinary capacities in advanced R\&D activities if consistent and smooth management strategies are used during R\&D studies and effective coordination skills are developed among employees. Innovative products produced because of $\mathrm{R} \& \mathrm{D}$ studies become a potential commercial value for the organization (Katila \& Ahuja, 2002). These studies are defined as all kinds of research that includes the development of skills, the development of innovative products and services, the innovation and process improvement, including innovation and process improvement, and the development of new jobs or the technology to be 
used (Matheson \& Matheson; 1999). Expenditures made in this field are one of the strongest variables that reveal the economic and technological development level of a country (Yaylalı et al., 2010).

Technopark communities are communication and coordination environments that enable enterprises to obtain their resources and skills from common pools and ensure that the R\&D portfolio can be shared strategically and in a balanced way. R\&D studies consist of strenuous activities that require patience and take quite a long time. These activities can only take place in an environment where the necessary persistence and motivation is provided, and proper communication and coordination is provided. Technopark provide communicative environments that can serve R\&D organizations exactly at this point. An innovative idea that emerges during $R \& D$ studies is created by $R \& D$ specialists working in the basic research phase. The emergence of a creative idea depends on the individual's skills, abilities, and capabilities. Considering the importance of the human factor and the technological resources used in the success of R\&D studies, the importance of the capabilities of R\&D specialists, availability of technological resources and innovative organizational structure becomes apparent. The approaches to be developed within the framework of resource-based theory and core competence-based strategies in determining $R \& D$ management strategies can make significant contributions to increasing $R \& D$ performance. These studies, which are an inevitable element of the digital age, have become necessary for a contemporary organization to compete with other organizations and to make its production more profitable. For this reason, it is very important to be able to shape $R \& D$ management activities with the right strategies. In today's world, technology and marketing-based strategies alone are not enough for the success of an R\&D organization. However, internal environment-oriented strategies are also needed. Technopark are very favorable environments for the implementation of core competence-based strategies in $R \& D$ management. Providing the knowledge and technology required for innovative products or producing innovative products through the internal coordination of existing professional knowledge will only be possible with core competence-based approaches. In our age where global competition reaches the highest levels, R\&D companies have to systematically manage technology, develop marketing strategies based on coordination and communication, and develop core competence-based strategies in a way that dominates the skill and ability levels of $\mathrm{R} \& \mathrm{D}$ professionals. Achieving high and meaningful results in $\mathrm{R} \& \mathrm{D}$ performance is possible by using technological resources and capabilities with a resource-based approach and as an input for applied research in an integrated manner. R\&D management strategies that need to be planned professionally are an inevitable precondition for an effective innovation management. Determining the R\&D management strategies and the R\&D performance to be measured based on these strategies in an accurate and integrated manner is of great importance in terms of establishing a healthy $R \& D$ policy. In this context, the development of R\&D management strategies and performance-oriented principles to be implemented in Technopark communities with a resource-based approach and an integrated logic based on competence-based strategies will provide significant benefits in increasing our national R\&D performance.

In this article, an R\&D governance model is proposed in the context of $R \& D$ policies to develop core competence-based strategies in Technopark communities. In the study, first of all, the theoretical infrastructure of $R \& D$ management and $R \& D$ performance was examined, and the results of literature reviews for R\&D performance were included. Then Technology Value Pyramid, which hierarchically explains the performance measurements of R\&D organizations, is explained. To better understand the mentioned framework, the basic principles of resource-based theory and core competence-based approach have been examined. Then, by considering the relationship between basic skill-based approach and R\&D performance, model proposals developed for the implementation of core competence-based strategies in Technopark were discussed with theoretical and practical examples.

Keywords: R\&D Management, Strategy, Core-Competence, Technopark

\section{Kaynakça}

Abbey, A. ve Dickson, J. W. (1983). R\&D Work Climate and Innovation in Semiconductors. Academy of Management Journal. Vol.26, No.2, 362-368. 
Asakawa, K., Nakamura, H. ve Sawada, N. (2010). Firms' Open Innovation Policies, Laboratories' External Collaborations, and Laboratories' R\&D Performance. R\&D Management, 40(2), 109-123.

Barney, J.B. (1986). Organizational Culture can It be a Source of Sustained Advantage? Academy of Management Review.

Barney, J.B. (1991). Firm Resources and Sustained Competitive Advantage. Journal of Management, Vol. 17, No.1.

Barutçugil, İ. (2009). Ar-Ge Yönetimi, İstanbul: Kariyer Yayınları.

Boxall, P. F. (1996). The Strategic HRM Debate and The Resource-Based View of The Firm. Human Resource Management Journal, 6 (3), ss. 59-75.

Bremser, W.G. ve Barsky, N.P. (2004). Utilizing the Balanced Scorecard for R\&D Performance Measurement. R\&D Management, Vol. 34/3, 229-238.

Brown, M. ve Svenson, R. (1988). Measuring R\&D Productivity. Research Technology Management, 31, 4, $11-15$.

Brown, W.B. ve Gobeli, D. (1992). Observations on The Measurement of R\&D Productivity: A Case Study. IEEE Transactions on Engineering Management, 39, 4, 325-331.

Campbell, A. ve Luchs, K.S. (2002). Temel Yetenek Tabanl Strateji: Rekabetçi İs Ortamonda Ayrrt Edici Özellikler, Epsilon Yayıncilık.

Chiesa, V., Frattini, F., Lazzarotti, V. ve Manzini, R. (2007). How Do Measurement Objectives Influence the R\&D Performance Measurement System Design? Evidence from a Multiple Case Study. Management Research Nens, 30(3), 187-202.

Cooper, R.G. and Kleinschmidt, E. (1996). Winning Businesses in Product Development: The Critical Success Factors. Research Technology Management, 39, 4, 18-29.

Cordero, R. (1990). The Measurement of Innovation Performance in the Firm: An Overview. Research Policy, 19, 2, 185-192.

Corley, K. G. ve Gioia, D. A. (2011). Building Theory about Theory Building: What Constitutes a Theoretical Contribution?. Academy of Management Review, 36(1), 12-32.

Driva, H., Pawar, K.S. ve Menon, U. (2000). Measuring Product Development Performance in Manufacturing Organizations. International Journal of Production Economics, 63, 147-159.

Drucker, P.F. (1996). Gelecek İçin Yönetim. 4. Baskı, Türkiye İş Bankası Kültür Yayınları, İstanbul.

Ellis, L.W. ve Curtis, C.C. (1995). Speedy R\&D: How Beneficial? Research Technology Management, 38, 4, 42-51.

Fey, C. F. ve Birkinshaw, J. (2005). External Sources of Knowledge, Governance Mode, and R\&D Performance. Journal of Management, 31(4), 597-621. $33,1$.

Foss, N. J. (1996). Research in Strategy, Economics, and Michael Porter. Journal of Management Studies,

Grant, R. M. (1991). The Resource-Based Theory of Competitive Advantage: Implications for strategy formulation. Califormia Management Review. s. 125.

Grant, R.M., (1996). Toward a Knowledge-Based Theory of the Firm. Strategic Management Journal, 17.

Griffin, A. ve Page A.L. (1996). PDMA Success Measurement Project: Recommended Measures for Product

Development Success and Failure. The Journal of Product Innovation Management, 13, 478-496.

Harrison, J.S., Hitt, M. A., Hoskisson, R.E. ve Ireland R.D. (1991). Synergies and Post-Acquisition

Performance: Differences Versus Similarities in Resource Allocations. Journal of Management, Vol. 17, No. 1.s. $173-175$.

Hauser, J. ve Zettelmeyer, F. (1997). Metrics to Evaluate R,D\&E. Research Technology Management, 40, 4, 32-38.

Hultink, E.J. ve Robben, H.S.J. (1995). Measuring New Product Success: The Difference That Time Perspective Makes. The Journal of Product Innovation Management, 12, 392-405.

Hung, C. L., Kuo, S. J. ve Dong, T. P. (2013). The Relationship Between Team Communication, Structure, and Academic R\&D Performance: Empirical Evidence of the National Telecommunication Program in Taiwan. R\&D Management, 43(2), 121-135. 
No:1.

Javidan, M. (1998). Core Competence: What Does It Mean in Practice? Long Range Planning, Vol:31,

Jenster, P. V. ve Pedersen, H. S. (2000). Outsourcing-Facts and Fiction, Strategic Change, Vol.9, pp. 147154.

Kalça, A. ve Atasoy, Y. (2008). Ekonomik Büyüme Aracı Olarak Bilgi Yatırımları ve İnovasyon, Bilgi Ekonomisi ve Yönetimi Dergisi, Cilt: III, Say1:II, 95-110.

Katila, R. ve Ahuja, G. (2002). Something Old, Something New: A Longitudinal Study of Search Behavior and New Product Introduction. Academy of Management Journal, 45(6), 1183-1194.

Katz, R. ve Allen, T. J.(1985). Project Performance and the Locus of Influence in the R\&D Matrix. The Academy of Management Journal, 28(1), 67-87.

Kerssens-van Drongelen, I.C. ve Bilderbeek, J. (1999). R\&D Performance Measurement: More Than Choosing a Set of Metrics. R\&D Management, 29, 1, 35-46.

Kim, B. ve Oh, H. (2002). An Effective R\&D Performance Measurement System: Survey of Korean $\mathrm{R} \& \mathrm{D}$ researchers. The International Journal of Management Science, 30, 19-31.

Lazzarotti, V., Manzini, R. ve Mari, L. (2011). A Model for R\&D Performance Measurement. International Journal of Production Economics, 134(1), 212-223.

Lee, M., Son, B. ve Lee, H. (1996). Measuring R\&D Effectiveness in Korean Companies. Research Technology Management, 39, 6, 28-31.

Leonard-Barton, D. (1992). Core Capabilities, Core Rigidities: A Paradox in Managing New Product Development. Strategic Management Journal, Summer Special Issue, 13, s.113.

Lepak, D.P. ve Snell, S. A. (1999). The Human Resource Architecture: Toward a Theory of Human Capital Allocation and Development. Academy of Management Review, 24, ss. 31-48.

Lichtenberg, F. R. 2002. Sources of U.S. longevity increase, 1960-1997, NBE. Working Paper, National Bureau of Economic Research, No: 8755

Major, E., Asch. D. ve Cordey-Hayes M. (2001). Foresight as a Core Competence. Futures 33, pp.91107.

Martin, B. R. (2016). R\&D Policy İnstruments-A Critical Review of What We Do and Don't Know. Industry and Innovation, 23(2), 157-176.

Matheson, D. ve Matheson, J. (1999). Akill Örgüt, Boyner Holding Yayınevi, İstanbul.

Meyer, M.H., Tertzakian, P. ve Utterback, J.M. (1997). Metrics for Managing Research and

Development in the Context of the Product Family, Management Science, 43, 1, 88-111.

Mooney, A. (2007). Core Competence, Distinctive Competence, and Competitive Advantage: What is the Difference? Journal of Education for Business, pp.110-115.

MÜSİAD Araştırma Raporlar1. (2012). Küresel Rekabet için Ar-Ge ve Inovasyon. Stratejik Dönüsüm Önerisi.

MÜSİAD Araştırma Raporları.

OECD. 2011, OECD Science, Technology and Industry Scoreboard 2011, OECD Publishing.

Ojanen, V. ve Vuola, O. (2003). Categorizing the Measures and Evaluation Methods of R \& D

Performance: A State-of-the-art Review on R\&D Performance Analysis. Lappeenranta University of Technology.

Özer, M. A. (2006). Yönetişim Üzerine Notlar. Sayıștay Dergisi, ISSN: 1300 - 1981.

Pitt, M. ve Clarke, K. (1999). Competing on Competence: A Knowledge Perspective on the

Management of Strategic Innovation. Technology Analysis \& Strategic Management, 11(3), s.301.

Prahalad, C.K. ve Hamel, G. (1990). The Core Competence of the Corporation. Harvard Business Revieww.

Reed, R. ve Defillippi, R.J. (1990). Causal Ambiguity, Barriers to İmitation, and Sustainable

Competitive Advantage. Academy of Management Review, Vol: 15, No:1.

Rumelt, R. P. (1987). Theory, strategy, and entrepreneurship. The Competitive Challenge, 137(158), 1-22.

Sanchez, R. ve Henee, A. (1997). Reinventing Strategic Management: New Theory and Practice for

Competence-Based Competition. European Management Journal, Vol. 15, No.3.

Schilling, M. A. ve Hill, C. W. (1998). Managing the New Product Development Process: Strategic Imperatives. The Academy of Management Executive, 12(3), 67-81. 
Schumann, P., Ransley, D. ve Prestwood, D. (1995). Measuring R\&D Performance. Research Technology Management, 38, 3, 45-54.

Srivastava, R. J., Fahey, L. ve Chiristensen, H. K. (2001). The Resource-Based View and Marketing: The Role of Market-Based Assets in Gaining Competitive Advantage. Journal of Management, 27, ss. 777802.

Taymaz, E., (2001). Ulusal Yenilik Sistemi: Türkiye Imalat Sanayinde Teknolojik Değğşim ve Yenilik Süreçleri, TÜBİTAK/TTGV/DİE, Ankara.

Tipping, J.W., Zeffren, Z. Fusfeld A.R. (1995). Assessing the Value of Your Technology. ResearchTechnology Management, 38, 22-39.

Torkkeli, M. ve Tuominen, M. (2002). The Contribution of Technology Selection to Core Competencies. International Journal of Production Economics, Vol: 77.

TÜBİTAK. 2004. Ulusal Bilim ve Teknoloji Politikalar1, 2003-2023 Strateji Belgesi.

Werner, B.M. ve Souder, W.E. (1997a). Measuring R\&D Performance - State of the Art. Research Technology Management, 40, 2, 34-42.

Wernerfelt, B., (1984). A Resource-Based View of the Firm. Strategic Management Journal, Vol.5, No. 2.

Wright, P. M., Dunford, B.B. ve Snell, S.C. (2001). Human Resources and the Resource Based View of the Firm. Journal of Management, Vol.27, ss. 701-721.

Yaylalı M. ve Akan Y., Işık, C. (2010). Türkiye'de Ar-Ge Yatırım Harcamaları ve Ekonomik Büyüme Arasındaki Eş Bütünleşme ve Nedensellik İlişkisi. Bilgi Ekonomisi ve Yönetimi Dergisi, Cilt: V Sayı: II. 